\title{
Cholinergic-Dependent Plateau Potential in Hippocampal CA1 Pyramidal Neurons
}

\author{
Douglas D. Fraser and Brian A. MacVicar \\ Neuroscience Research Group, Faculty of Medicine, University of Calgary, Calgary, Alberta, Canada T2N 4N1
}

\begin{abstract}
Cholinergic stimulation of the hippocampal formation results in excitation and/or seizure. We report here, using whole-cell patch-clamp techniques in the hippocampal slice $\left(34-35^{\circ} \mathrm{C}\right)$, a cholinergic-dependent slow afterdepolarization (SADP) and long-lasting plateau potential (PP). In the presence of $20 \mu \mathrm{M}$ carbachol, action potential firing evoked by weak intracellular current injection elicited an SADP that lasted several seconds. Increased spike firing evoked by stronger depolarizing stimuli resulted in long-duration PPs maintained close to $-20 \mathrm{mV}$. Removal of either $\mathrm{Na}^{+}$or $\mathrm{Ca}^{2+}$ from the external media, intracellular $\mathrm{Ca}^{2+} \quad\left(\left[\mathrm{Ca}^{2+}\right]_{\mathrm{i}}\right)$ chelation with $10 \mathrm{~mm}$ bis(2aminophenoxy)ethane- $N, N, N^{\prime}, N^{\prime}$-tetra-acetic acid, or the addition of $100 \mu \mathrm{M} \mathrm{Cd}{ }^{2+}$ to the perfusate abolished both the sADP and PP. The sADP was depressed and the PP was abolished by either $10 \mu \mathrm{M}$ nimodipine or $1 \mu \mathrm{M} \omega$-conotoxin, whereas $1.2 \mu \mathrm{M}$ tetrodotoxin was ineffective. The involvement of a $\mathrm{Na}^{+} / \mathrm{Ca}^{2+}$ exchanger was minimal because both the sADP and PP persisted after equimolar substitution of $50 \mathrm{mM} \mathrm{Li}^{+}$for $\mathrm{Na}^{+}$in the
\end{abstract}

external media or reduction of the bath temperature to $25^{\circ} \mathrm{C}$. Finally, in the absence of carbachol the sADP and PP could not be evoked when $\mathrm{K}^{+}$channels were suppressed, suggesting that depression of $\mathrm{K}^{+}$conductances alone was not sufficient to unmask the conductance. Based on these data, we propose that a $\mathrm{Ca}^{2+}$-activated nonselective cation conductance was directly enhanced by muscarinic stimulation. The sADP, therefore, represents activation of this conductance by residual $\left[\mathrm{Ca}^{2+}\right]_{\mathrm{i}}$, whereas the PP represents a novel regenerative event involving the interplay between high-voltage-activated $\mathrm{Ca}^{2+}$ channels and the $\mathrm{Ca}^{2+}$-activated nonselective cation conductance. This latter mechanism may contribute significantly to ictal depolarizations observed during cholinergic-induced seizures.

Key words: muscarinic stimulation; $\mathrm{Ca}^{2+}$-activated nonselective cation conductance; HVA $\mathrm{Ca}^{2+}$ currents; ictal depolarization; epilepsy; slice-patch technique
The hippocampal formation receives cholinergic afferents from the medial septum/diagonal band that terminate on dendritic segments located in both the cornu Ammonis and dentate gyrus (Wainer et al., 1993). This septohippocampal pathway is critical in the generation of rhythmical slow activity (Bland, 1986; Vanderwolf, 1988) and is implicated in some forms of learning and memory (Shen et al., 1994). Cholinergic stimulation is also effective in generating limbic seizures and, thus, injection of cholinergic agents is used as a model for temporal lobe epilepsy (Lothman et al., 1991). Indeed, hippocampal sclerosis after infusion of cholinergic agonists accurately mimics numerous pathological indices of human status epilepticus (Wasterlain et al., 1993).

The electrophysiological actions of cholinergic agonists on neurons have been studied extensively in vitro and, for the most part, are considered excitatory (Halliwell, 1990; Krnjević, 1993; McCormick, 1993). For example, cholinergic stimulation causes a sustained depolarization associated with an increased input resistance $\left(R_{\mathrm{IN}}\right)$ and depression of spike frequency adaptation. These effects are attributed to a cholinergic-induced depression of four potassium conductances, including the M-current $\left(I_{M}\right)$ (Halliwell

Received Feb. 27, 1996; revised April 2, 1996; accepted April 8, 1996.

This work was supported by a grant from the Medical Research Council of Canada (MRC). D.D.F. is a recipient of studentships from the MRC, Alberta Heritage Foundation for Medical Research (AHFMR), and Savoy Foundation for Epilepsy Research. B.A.M. is an AHFMR scientist and the Ciba Geigy chair for schizophrenia research. We are grateful to Drs. S. Barnes and G. Spencer for critical comments on this manuscript and Drs. A. R. McQuiston and W. F. Colmers for slice-patch advice.

Correspondence should be addressed to Douglas D. Fraser, Department of Neuroscience, 3330 Hospital Drive N.W., Health Sciences Building, University of Calgary, Alberta, Canada, T2N 4N1.

Copyright (C) 1996 Society for Neuroscience $0270-6474 / 96 / 164113-16 \$ 05.00 / 0$ and Adams, 1982; Madison et al., 1987), a fast inactivating current $\left(I_{\mathrm{A}}\right)$ (Nakajima et al., 1986), a slow $\mathrm{Ca}^{2+}$-activated current $\left(I_{\mathrm{AHP}}\right)$ (Madison et al., 1987; Bernardo and Prince, 1982), and a background leak current $\left(I_{\text {LEAK }}\right)$ (Madison et al., 1987). Voltagedependent $\mathrm{Ca}^{2+}$ channels are also modulated by cholinergic stimulation; high-voltage-activated (HVA) channels are depressed ( $I_{\text {HVA }}$ ) (Misgeld et al., 1986; Toselli and Lux, 1989), whereas low voltage-activated channels are enhanced $\left(I_{\text {LVA }}\right)$ (Toselli and Lux, 1989; Fraser and MacVicar, 1991). More recently, a nonselective cation conductance has been demonstrated to contribute to the initial cholinergic-induced depolarization (Benson et al., 1988; Shen and North, 1992; Colino and Halliwell, 1993). A slow afterdepolarization (SADP) has also been observed in the presence of cholinergic agents (Bernardo and Prince, 1982; Gähwiler, 1984; McCormick and Prince, 1986; Müller et al., 1988; Hasuo and Gallagher, 1990; Andrade, 1991; Müller and Connor, 1991), however, multiple ionic mechanisms may underlie this phenomenon. For instance, a $\mathrm{Na}^{+} / \mathrm{Ca}^{2+}$ exchanger (Friedman et al., 1992), a prolonged $\mathrm{Ca}^{2+}$ conductance (Blitzer et al., 1991), deactivation of a $\mathrm{K}^{+}$conductance by maintained $\mathrm{Ca}^{2+}$ influx (Constanti and Bagetta, 1991; Constanti et al., 1993), and a $\mathrm{Ca}^{2+}$-activated nonselective cation conductance $\left(I_{\mathrm{CAN}}\right)$ (Schwindt et al., 1988; Hasuo et al., 1990; Caeser et al., 1993) are all plausible mechanisms.

Although there are multiple reports of sADPs after muscarinic stimulation, cholinergic-dependent plateau potentials (PPs) have not been reported. This PP may represent a novel regenerative event involving interactions between $I_{\mathrm{HVA}}$ and $I_{\mathrm{CAN}}$. It is conceivable that interplay between these channels could contribute significantly to ictal depolarizations observed during cholinergic- 
Table 1. Membrane properties of CA1 pyramidal neurons under whole-cell current clamp

\begin{tabular}{|c|c|c|c|c|c|c|c|}
\hline & $r p(\mathrm{mV})$ & $R_{\mathrm{IN}}(\mathrm{M} \Omega)$ & $A P_{\mathrm{AMP}}(\mathrm{mV})$ & $A P_{\mathrm{TH}}(\mathrm{mV})$ & $A P_{\text {DUR }}(\mathrm{msec})$ & $\tau(\mathrm{msec})$ & $n$ \\
\hline K-gluconate ${ }^{a}$ & $-65 \pm 0.1$ & $149 \pm 3$ & $92 \pm 1$ & $-47 \pm 0.3$ & $1.6 \pm 0.01$ & $20.7 \pm 0.4$ & 188 \\
\hline Cs-gluconate ${ }^{b}$ & $-59 \pm 0.7$ & $183 \pm 12$ & - & - & - & $23.6 \pm 1.8$ & 11 \\
\hline $\mathrm{KCl}^{c}$ & $-65 \pm 0.4$ & $173 \pm 24$ & $92 \pm 5$ & $-48 \pm 1.3$ & $1.8 \pm 0.06$ & $22.8 \pm 3.0$ & 8 \\
\hline BAPTA $^{d}$ & $-67 \pm 1.9$ & $164 \pm 47$ & $88 \pm 2$ & $-45 \pm 1.4$ & $2.4 \pm 0.15$ & $21.6 \pm 1.1$ & 4 \\
\hline
\end{tabular}

Abbreviations: $r p$, resting potential; $R_{\mathrm{IN}}$, input resistance; $A P_{\mathrm{AMP}}$, action potential amplitude; $A P_{\mathrm{TH}}$, action potential threshold; $A P_{\mathrm{DUR}}$, action potential duration; $\tau$, tau. Intracellular solutions (in $\mathrm{mm}$ ):

${ }^{a} 140$ K-gluconate; 1.1 EGTA; $0.1 \mathrm{CaCl}_{2} ; 10$ HEPES; 2 Mg-ATP; 0.3 Na-GTP.

${ }^{b} 40$ Cs-gluconate; $100 \mathrm{~K}$-gluconate; 1.1 EGTA; $0.1 \mathrm{CaCl}_{2}$; $10 \mathrm{HEPES} ; 2 \mathrm{Mg}$-ATP; $0.3 \mathrm{Na}$-GTP.

c70 KCl; $70 \mathrm{~K}$-gluconate; 1.1 EGTA; $0.1 \mathrm{CaCl}_{2}$; 10 HEPES; $2 \mathrm{Mg}$-ATP; $0.3 \mathrm{Na}$-GTP.

d100 K-gluconate; 10 K-BAPTA; 40 HEPES; 2 Mg-ATP; 0.3 Na-GTP.

induced seizures (Lothman et al., 1991). The aim of the present study, therefore, was to identify the ionic mechanisms underlying the cholinergic-induced PP recorded in hippocampal CA1 pyramidal neurons with whole-cell patch-clamp techniques.

These results have been presented in abstract form (Fraser and MacVicar, 1995).

\section{MATERIALS AND METHODS}

Hippocampal slice preparation. Sprague-Dawley rats, postnatal 15-23 d, were decapitated and the brains were immersed in chilled artificial CSF (aCSF) containing (in mM): $126 \mathrm{NaCl}, 2.5 \mathrm{KCl}, 2 \mathrm{MgCl}_{2}, 2 \mathrm{CaCl}_{2}, 1.25$ $\mathrm{NaH}_{2} \mathrm{PO}_{4}, 26 \mathrm{NaHCO}_{3}^{-}$, and 10 D-glucose, $\mathrm{pH}$ 7.3. The hippocampi were isolated and attached to the stage of a vibrating micro-slicer with cyanoacrylate glue. Tissue orientation and stability were ensured by propping the hippocampi against an immobilized block of $2 \%$ agar dissolved in physiological saline followed by a light application of low-melt gelatin around the tissue base. Transverse slices $(150-400 \mu \mathrm{m})$ were prepared by sectioning the hippocampus perpendicular to its septotemporal axis. The slices were then transferred to a glass vial filled with oxygenated aCSF and incubated at room temperature.

Whole-cell patch-clamp recording. Whole-cell current-clamp recordings from neurons within hippocampal slices were obtained using either the "blind-patch" technique (Blanton et al., 1989) or visual guidance (Edwards et al., 1989). Slices were individually transferred to a recording chamber located on an upright microscope (Standard 14; Zeiss, Thornwood, NY) and submerged in rapidly flowing $(1 \mathrm{ml} / \mathrm{min})$ oxygenated aCSF. Bath temperature was maintained at $34-35^{\circ} \mathrm{C}$ with a Peltier unit and Cambion bipolar controller. Individual cells were visualized through a $40 \times, 0.75$ numerical aperture, water-immersion objective (Zeiss). The objective was first modified by filing away the metal shoulder around the lens (Brown and Flaming, 1992). This improved the working space beside the lens, thereby increasing the angle of electrode approach. The objective was then coated with SYLGARD for temperature and electrical isolation. Patch electrodes (5-7 M $\Omega$ ) were pulled from 1.5 outer diameter thin-walled glass (150F-4, World Precision Instruments) in two stages on a Narishige puller (PP-83; Tokyo, Japan) and filled with intracellular solution (in mM): $140 \mathrm{~K}$-gluconate, 1.1 EGTA, $0.1 \mathrm{CaCl}_{2}, 10 \mathrm{HEPES}, 2$ $\mathrm{Mg}$-ATP, and 0.3 Na-GTP, pH 7.2. Intracellular $\mathrm{Ca}^{2+}$ concentration was calculated to be $16 \mathrm{nM}$. In some experiments, Cs-gluconate or $\mathrm{KCl}$ was substituted for equimolar K-gluconate (see Table 1 for description of intracellular solutions). Voltage recordings were obtained in bridge mode (Axoclamp-2A, Axon Instruments, Foster City, CA) and were low-pass filtered (4-pole Bessel) at $10 \mathrm{kHz}(-3 \mathrm{~dB})$. Capacitance neutralization was fully maximized, and the voltage drop across the electrode patch was subtracted by bridge circuit potentiometer. Data were digitized and analyzed using computer software (pClamp or Axotape) via a Tl-1 A/D interface (Axon Instruments). All data are presented as mean \pm SE.

Measurement of electrophysiological properties. Membrane characteristics were determined after patch rupture and sampled throughout the experiment. Series resistance was determined via a bridge potentiometer by balancing the voltage drop across the patch in response to a negative current pulse $(-30 \mathrm{pA} ; 10 \mathrm{msec}) . R_{\mathrm{IN}}$ was calculated from a steady-state potential response, free of membrane rectification, to a hyperpolarizing current step. The membrane time constant $(\tau)$ was calculated as the time necessary to reach $1-e^{-1}(63 \%)$ of the maximum voltage deflection. Action potential threshold $\left(A P_{\mathrm{TH}}\right)$ was measured as the membrane po- tential at the base of the action potential, whereas, action potential amplitude $\left(A P_{\mathrm{AMP}}\right)$ was measured as the voltage difference between the threshold and peak amplitude. Action potential duration $\left(A P_{\text {DUR }}\right)$ was measured at the threshold potential.

\section{RESULTS}

The results in this paper were obtained from 211 CA1 pyramidal neurons in the hippocampal slice preparation, recorded with whole-cell patch-clamp techniques. The average series resistance was $14.0 \pm 0.2 \mathrm{M} \Omega$ (range $8-20 ; n=211$ ); recordings with series resistance $>20 \mathrm{M} \Omega$ were discarded. The resting membrane potential, input resistance, membrane time constant, and action potential characteristics were similar to those reported previously (see Table 1) (Stabel et al., 1992; Williams et al., 1994).

\section{Cholinergic stimulation of CA1 pyramidal neurons}

Hippocampal CA1 pyramidal neurons were stimulated by bath application of carbachol, a nonhydrolyzable cholinergic agonist. Consistent with previous reports, $20 \mu \mathrm{M}$ carbachol depolarized the membrane potential by $3-11 \mathrm{mV}(n=188)$ and increased $R_{\mathrm{IN}}$ by $16 \pm 1 \%$ (range 5-30; 50 neurons sampled). Spike frequency adaptation was reduced, and the action potential afterhyperpolarization was abolished (Fig. 1A). In thicker slices (300-400 $\mu \mathrm{m})$, an increase in synaptic noise was commonly observed with carbachol application that could be differentiated into discrete excitatory and inhibitory postsynaptic potentials (data not shown) (MacVicar and Tse, 1989; Pitler and Alger, 1992; Behrends and Bruggencate, 1993). These effects were antagonized by coapplication of atropine $(n=7 / 7)$, indicating that carbachol acted specifically at muscarinic receptors, as shown previously (Halliwell, 1990). At a concentration of $20 \mu \mathrm{M}$, however, carbachol failed to induce rhythmic membrane potential oscillations or theta activity, reported previously for higher concentrations $(>50 \mu \mathrm{M})$ (Konopacki et al., 1987; MacVicar and Tse, 1989).

\section{Cholinergic-dependent sADP and PP}

In the absence of a cholinergic agonist, positive current injection $(\geq 0.1 \mathrm{nA})$ resulted in repetitive action potential firing in all CA1 pyramidal neurons tested (Fig. $1 A, B ; n=196$ ). After cessation of current injection, the membrane potential rapidly returned to resting levels. In contrast, after a $5 \mathrm{~min}$ application of $20 \mu \mathrm{M}$ carbachol, weak current injection $(\sim 0.1 \mathrm{nA} ; 0.8 \mathrm{sec})$ resulted in repetitive firing at higher frequency, which was commonly superimposed on a depolarizing ramp. After cessation of evoked action potentials, a depolarizing afterpotential was observed that declined slowly over several seconds (Fig. $1 A, B ; n=188 / 188$ ). This potential was termed an SADP. The average duration and maximal amplitude of the sADP was $6.1 \pm 0.2 \mathrm{sec}$ (range $2.8-8.5 ; n=$ 
A control

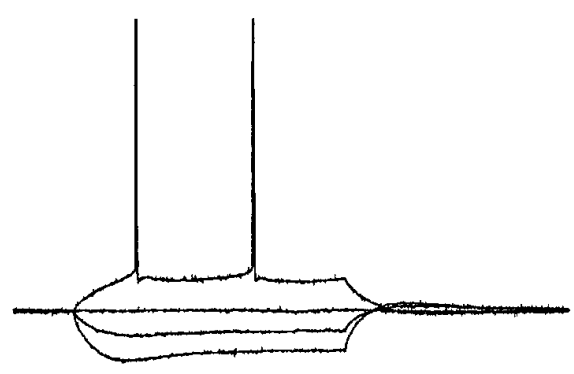

$20 \mu \mathrm{M}$ carbachol

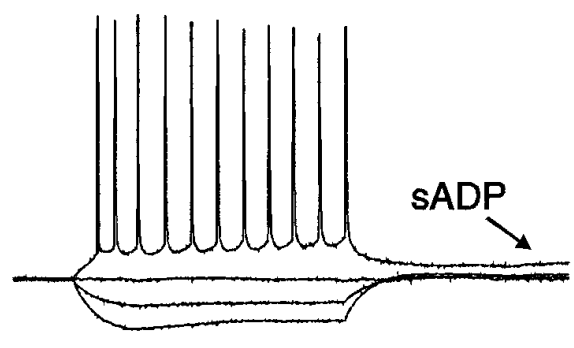

wash carbachol

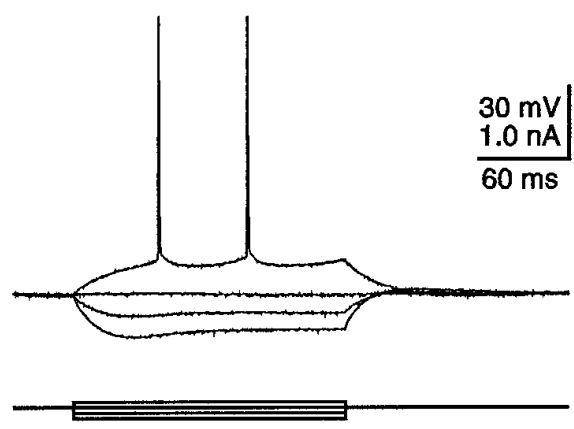

B

control

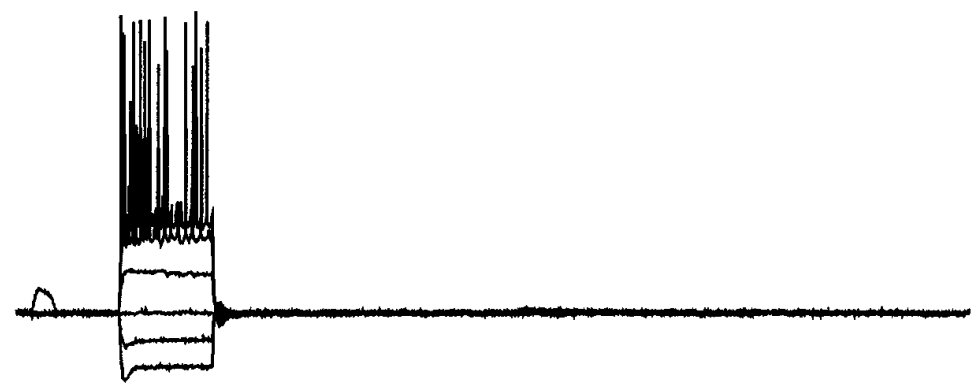

$20 \mu \mathrm{M}$ carbachol

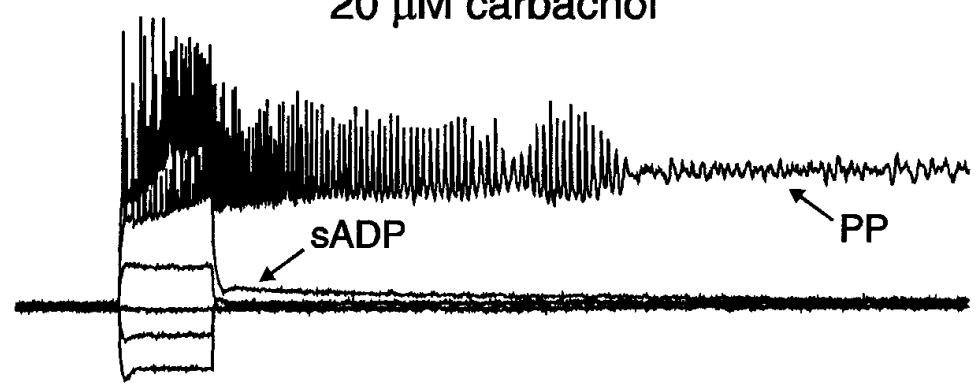

wash carbachol

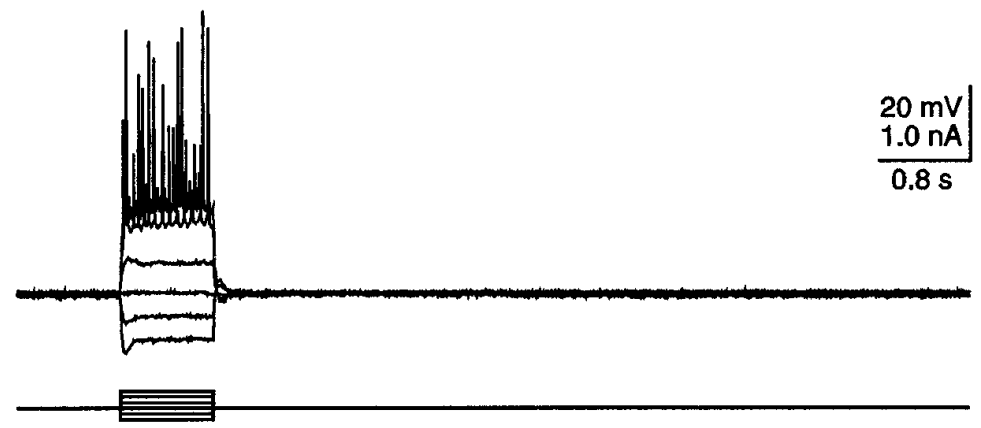

Figure 1. In the presence of carbachol, a nonhydrolyzable cholinergic agonist, depolarizing current injection resulted in either an sADP or a PP. $A$, Typical responses of a hippocampal CA1 pyramidal neuron to hyperpolarizing and depolarizing current injection. Neither an sADP nor a PP was observed in the absence of cholinergic agonists. The resting membrane potential of this neuron was $-66 \mathrm{mV}$. After application of $20 \mu \mathrm{M}$ carbachol, the membrane potential depolarized to $-60 \mathrm{mV}$, spike frequency adaptation was reduced, and the action potential afterhyperpolarization was abolished. In addition, an $s A D P$ (arrow) was now evident after cessation of the current stimulus. After a 20 min wash of carbachol, the membrane potential repolarized to $-64 \mathrm{mV}$, spike frequency adaptation was again observed, and the sADP was absent. At least one component of action potential afterhyperpolarization, however, failed to return after wash of carbachol. $B$, In a different CA1 pyramidal neuron, 0.8 sec depolarizing current injection resulted in a typical pattern of repetitive action potentials. The membrane potential returned to the baseline level after cessation of the stimuli. In the presence of $20 \mu \mathrm{M}$ carbachol, however, spike firing evoked by identical stimuli resulted in not only a slow afterdepolarization ( $s A D P$; arrow), but also a long-lasting plateau potential $(P P ;$ arrow $)$. Notice the low-amplitude oscillations superimposed on the latter portion of the PP. Both the sADP and PP were reversed after carbachol had been washed from the slice for $20 \mathrm{~min}$. Action potentials were truncated by the digitization rate.

50) and $9 \pm 1 \mathrm{mV}$ (range 3-20; $n=50$ ), respectively. Injection of stronger current $(\geq 0.2 \mathrm{nA})$ for the same duration resulted in higher frequency action potential firing superimposed on a steep depolarization that developed into a regenerative PP (Fig. $1 B ; n=$ 179/188). The average duration of the PP evoked under the above conditions was $9.9 \pm 0.6 \mathrm{sec}$ (range 2.2-21.5; $n=50$ ), whereas the average membrane potential of the PP was $-19 \pm 1 \mathrm{mV}$ (range -25 to $-11 ; n=50$; measured at $0.2 \mathrm{sec}$ after cessation of the stimuli). Oscillations in the membrane potential were commonly observed superimposed on the PP (Fig. $1 B$ ), probably consisting of $\mathrm{Na}^{+}$and/or $\mathrm{Ca}^{2+}$ oscillations well described by others (MacVicar, 1985; Alonso and Llinas, 1989; Leung and Yim, 1991; García-Muñoz et al., 1993). Both the sADP and PP were antag- onized by coapplication of $1 \mu \mathrm{M}$ atropine, again suggesting the specific involvement of muscarinic receptors (Fig. 2; $n=7 / 7$ ).

Each PP consisted of at least four distinct phases (Fig. 3A, arrows). The first phase consisted of a steep depolarizing shift that accompanied action potential firing during intracellular current injection. The second phase consisted of the prolonged PP. The third phase, lasting up to several seconds, was a repolarization that commonly hyperpolarized beyond the resting membrane potential. The final phase consisted of this hyperpolarization, which, over a prolonged period of time, returned to the baseline. The data in Figure $3 A$ also demonstrate the reproducibility of the PP waveform in any one cell. In this neuron, five PPs were evoked, separated by $10 \mathrm{~min}$ between stimuli. 

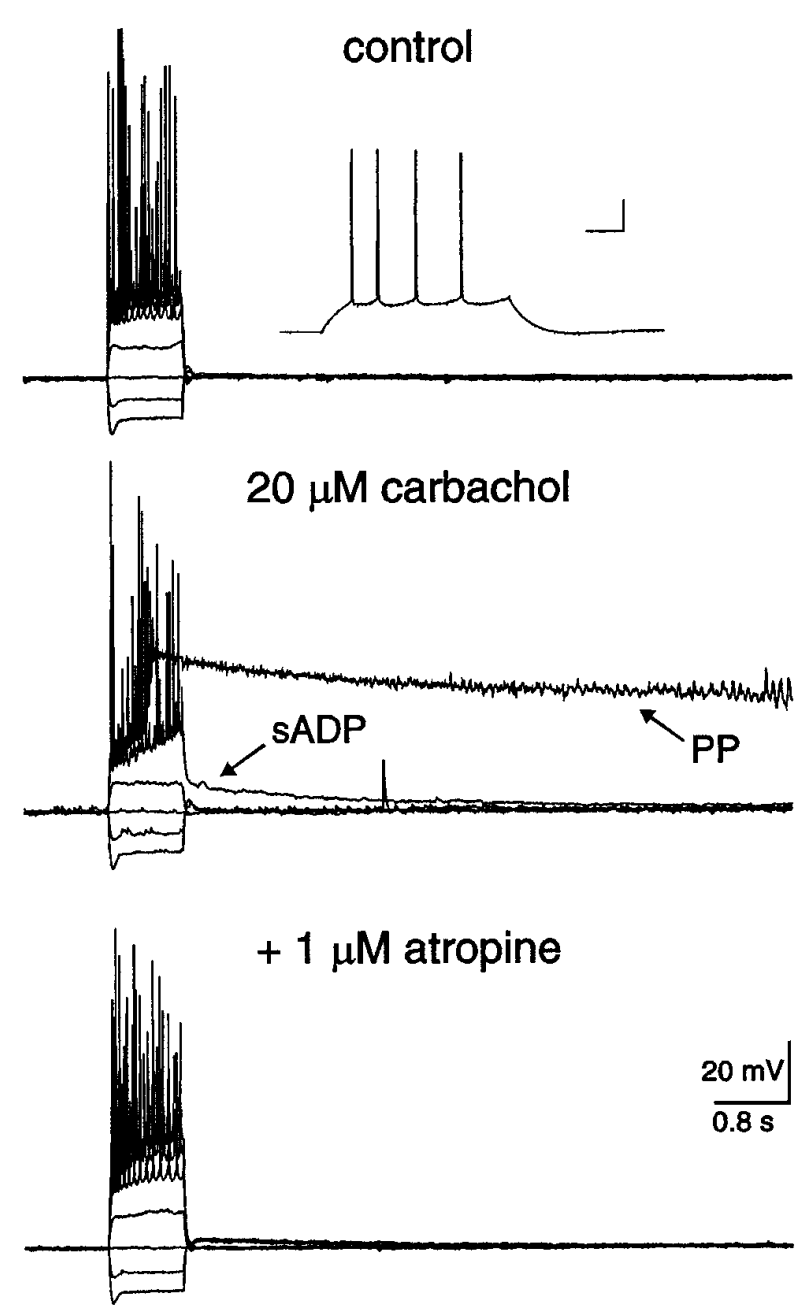

Figure 2. Both the SADP and PP were depressed by coapplication of the muscarinic receptor antagonist atropine. In control, the resting membrane potential of this neuron was $-65 \mathrm{mV}$, and neither the sADP nor the PP was observed after action potential firing. The inset illustrates the typical firing pattern of this CA1 pyramidal neuron. The calibration bars in the inset represent $40 \mathrm{msec}$ and $20 \mathrm{mV}$. In the presence of $20 \mu \mathrm{M}$ carbachol, the membrane potential depolarized to $-61 \mathrm{mV}$, and both the sADP and $\mathrm{PP}$ were observed after the spike firing. Coapplication of $1 \mu \mathrm{M}$ atropine depressed both the sADP and PP, implicating the involvement of muscarinic receptors.

Increasing the number of evoked action potentials enhanced the sADP amplitude until a critical threshold for PP genesis was achieved. For example, gradually increasing the intensity of the injected current resulted in increased spike firing (Fig. $3 B$ ). As a result, the amplitude of the SADP increased accordingly until the PP was elicited. Conversely, for a current pulse of a given amplitude, increasing the duration of the stimuli also increased the number of action potentials, thereby enhancing the SADP amplitude (Fig. 3C). A critical threshold for PP genesis was also obtained. Even though a clear transition from sADP to PP genesis was observed, the two phenomena may be related because both required cholinergic stimulation and followed a burst of action potentials.

The amplitude of the SADP and the duration of the PP were dependent on the holding potential (Fig. 4). As before, in the absence of a cholinergic agonist, the membrane potential returned to resting levels after a burst of evoked action potentials
(Fig. 4A). In the presence of carbachol, however, both the sADP and PP were observed after identical stimuli (Fig. $4 B$ ). The membrane potential in this case was maintained at $-60 \mathrm{mV}$ with positive DC current injection. The SADP and PP were differentially affected when evoked from more negative membrane potentials. For example, the sADP was hardly detectable below -75 $\mathrm{mV}$, and the duration of the PP was reduced with more negative membrane potentials (Fig. $4 C-E ; n=6 / 6$ ). The graph depicts the PP duration versus membrane potential (Fig. $4 F ; n=3$ ). The duration was measured from the end of the current pulse to the point at which the PP crossed or reached the prestimuli membrane potential. Notice the nonlinear DC current injection, also depicted in Figure $4 F(n=3)$, required to maintain the membrane at negative potentials. This indicates the activation of a steadystate conductance at these negative membrane potentials; the most likely candidate in this cell type is the hyperpolarizingactivated cation conductance (Halliwell and Adams, 1982; Stabel et al., 1992).

\section{lonic dependency of the SADP and PP}

The ion(s) mediating the sADP and PP were investigated either by substitution experiments or by including specific channel blockers in the perfusate. In the first experiment, a role for $\mathrm{Na}^{+}$was investigated by replacing extracellular $\mathrm{Na}^{+}$with equimolar choline. When extracellular $\mathrm{Na}^{+}$was reduced from 152 to $26 \mathrm{mM}$, both the sADP and PP were reversibly depressed (Fig. $5 A ; n=$ $6 / 6)$. A small amplitude sADP was still observed in low extracellular $\mathrm{Na}^{+}(6 \pm 1 \mathrm{mV}$; range 3-10; $n=6)$, however, the amplitude of the depolarizing current injected was twofold greater. In a similar experiment, both the sADP and PP were reversibly abolished when extracellular $\mathrm{Ca}^{2+}$ was reduced from 2 to $0.1 \mathrm{~mm}$ (Fig. $5 B ; n=4 / 4)$. In this experiment, extracellular $\mathrm{Mg}^{2+}$ was simultaneously increased from 2 to $10 \mathrm{~mm}$ to maintain the divalent cation surface charge (Hille, 1984). Finally, a role for $\mathrm{Cl}^{-}$was also investigated by equimolar substitution of $70 \mathrm{mM} \mathrm{KCl}$ for K-gluconate in the pipette solution (Table $1 ; n=8$ ). Even though the estimated $\mathrm{Cl}^{-}$reversal potential was shifted to $-17 \mathrm{mV}$, characteristic sADPs and PPs were still elicited in carbachol after depolarizing current injection and action potential firing (data not shown; $n=8 / 8$ ). Hence, $\mathrm{Na}^{+}$and $\mathrm{Ca}^{2+}$ influx were both critical for genesis of the sADP and PP, whereas the involvement of $\mathrm{Cl}^{-}$ was negligible.

To determine whether voltage-activated $\mathrm{Na}^{+}$channels were involved in SADP and PP genesis, $1.2 \mu \mathrm{M}$ tetrodotoxin (TTX) was included in the perfusate (Fig. $5 C ; n=5$ ). In all neurons, both the sADP and PP were still observed after application of TTX. In the presence of TTX, not only were fast action potentials blocked, but the low-amplitude oscillations observed superimposed on the PP were also abolished (MacVicar, 1985; Alonso and Llinas, 1989; Leung and Yim, 1991). In some neurons, a small amplitude sADP was observed after current injection in the absence of regenerative potentials (Fig. $5 C ; n=2 / 5$ ). The average duration and maximal amplitude were $4.8 \mathrm{sec}$ and $4 \mathrm{mV}$, respectively. The PP, however, was only observed after the depolarizing stimuli activated slow, regenerative potentials that were presumably $\mathrm{Ca}^{2+}$-dependent (Fig. 5C; $n=5$ ). These data clearly eliminate the involvement of TTX-sensitive, voltage-activated $\mathrm{Na}^{+}$channels in genesis of the SADP and PP. To determine whether HVA $\mathrm{Ca}^{2+}$ channels were required for genesis of the SADP and $\mathrm{PP}, 100 \mu \mathrm{M} \mathrm{Cd}{ }^{2+}$ was included in the perfusate (Fig. $5 D)$. In all neurons $(n=4)$, both the sADP and PP were blocked by coapplication of $\mathrm{Cd}^{2+}$, suggesting a critical role for $\mathrm{HVA} \mathrm{Ca}^{2+}$ channels in genesis of these afterpotentials. In fact, 

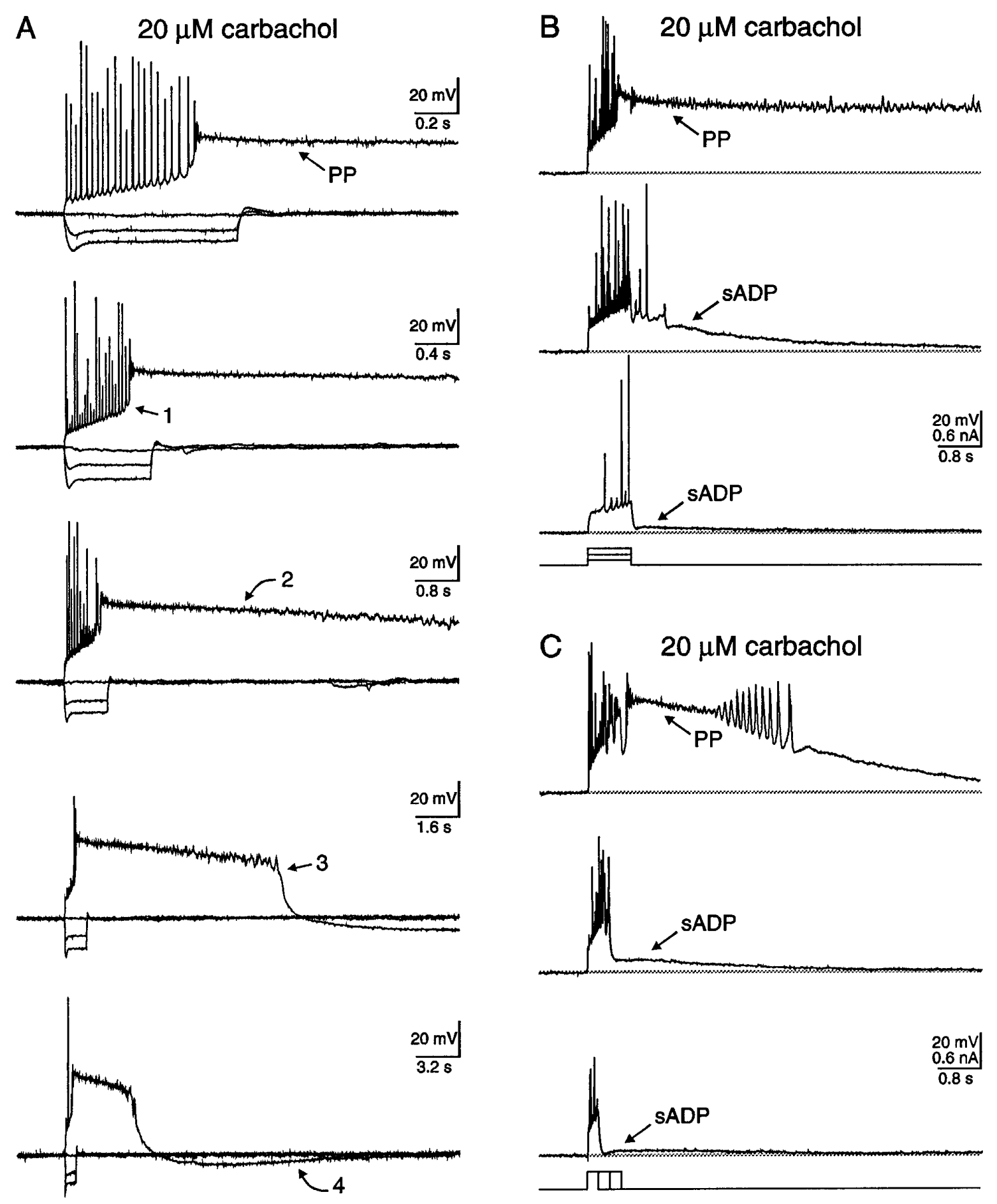

Figure 3. The cholinergic-dependent PP consisted of at least four distinct phases, and the likelihood of generating a PP increased with the number of action potentials elicited. $A$, In the absence of cholinergic stimulation, the resting membrane potential of the neuron illustrated was $-67 \mathrm{mV}$. Application of $20 \mu \mathrm{M}$ carbachol depolarized this neuron to $-62 \mathrm{mV}$. In addition, action potential firing evoked by depolarizing current injection (0.1 nA; $0.8 \mathrm{sec})$ elicited a long-lasting plateau potential in the CA1 pyramidal neuron illustrated. Notice that the spikes are superimposed on a depolarizing ramp that jumped suddenly to a depolarized membrane potential of $-20 \mathrm{mV}$ (phase 1; arrow). The PP remained at positive membrane potentials for a sustained period, long after cessation of the current injection ( phase 2; arrow). After a prolonged period, the PP repolarized, surpassing the resting potential ( phase 3; arrow). Finally, the membrane potential remained at a hyperpolarized potential for a period of $\sim 19$ sec before a gradual return to the resting potential (phase 4; arrow). The PP was evoked five times and digitized on line at five different rates to illustrate not only the distinct phases of the PP, but also the reproducibility of the waveform. Action potentials were truncated by the digitization rate. $B$, In the presence of $20 \mu \mathrm{M}$ carbachol, the likelihood of generating a PP increased with the magnitude of depolarizing current injection. The responses to three amplitudes of current injection $(0.1,0.2,0.3 \mathrm{nA}$; $0.8 \mathrm{sec}$ ) are illustrated. The resting membrane potential of the neuron before cholinergic stimulation was $-68 \mathrm{mV}$, whereas in carbachol the neuron depolarized to $-59 \mathrm{mV}$. C , The probability of generating a PP in carbachol also increased with the duration of depolarizing current injection. Depolarizing current injection for three durations $(0.2,0.4,0.6 \mathrm{sec} ; 0.3 \mathrm{nA})$ is illustrated. The resting membrane potential of the neuron before cholinergic stimulation was $-72 \mathrm{mV}$, whereas in carbachol the neuron depolarized to $-65 \mathrm{mV}$. 
A control

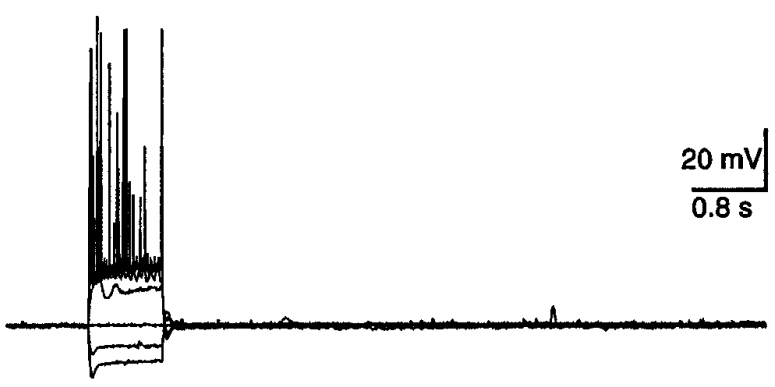

B $20 \mu \mathrm{M}$ carbachol $\backslash-60 \mathrm{mV}(+20 \mathrm{pA})$

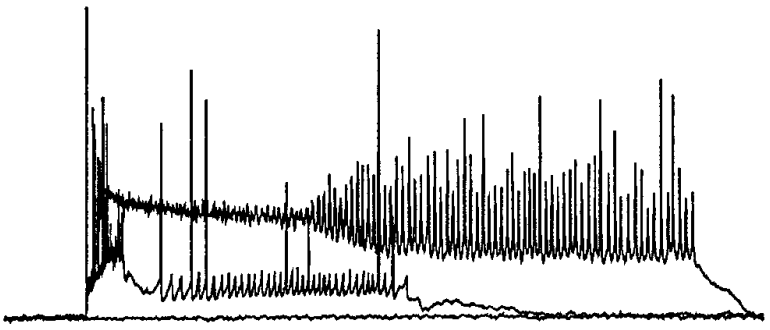

C $20 \mu \mathrm{M}$ carbachol $\backslash-65 \mathrm{mV}(-10 \mathrm{pA})$

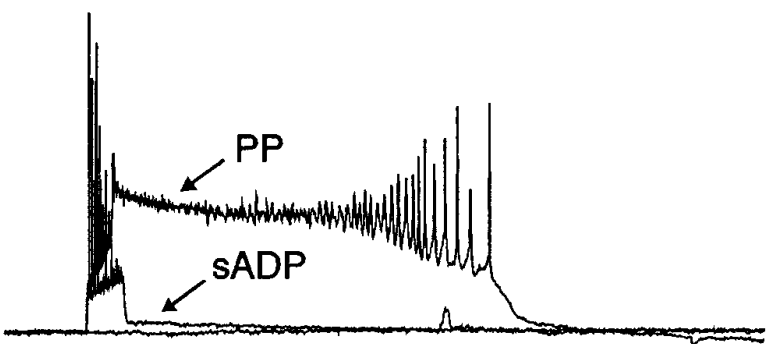

D $20 \mu \mathrm{M}$ carbachol $\backslash-70 \mathrm{mV}(-90 \mathrm{pA})$

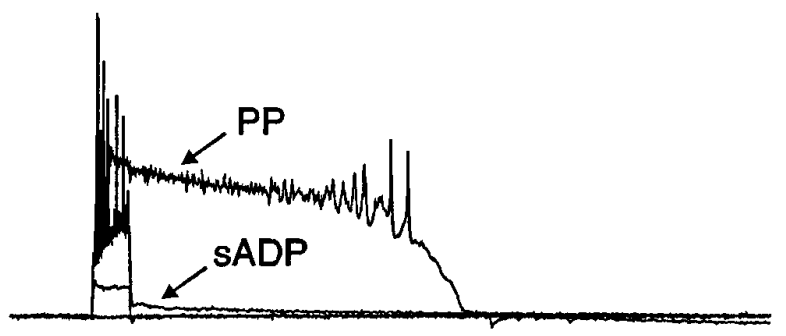

E $20 \mu \mathrm{M}$ carbachol $\backslash-75 \mathrm{mV}(-200 \mathrm{pA})$
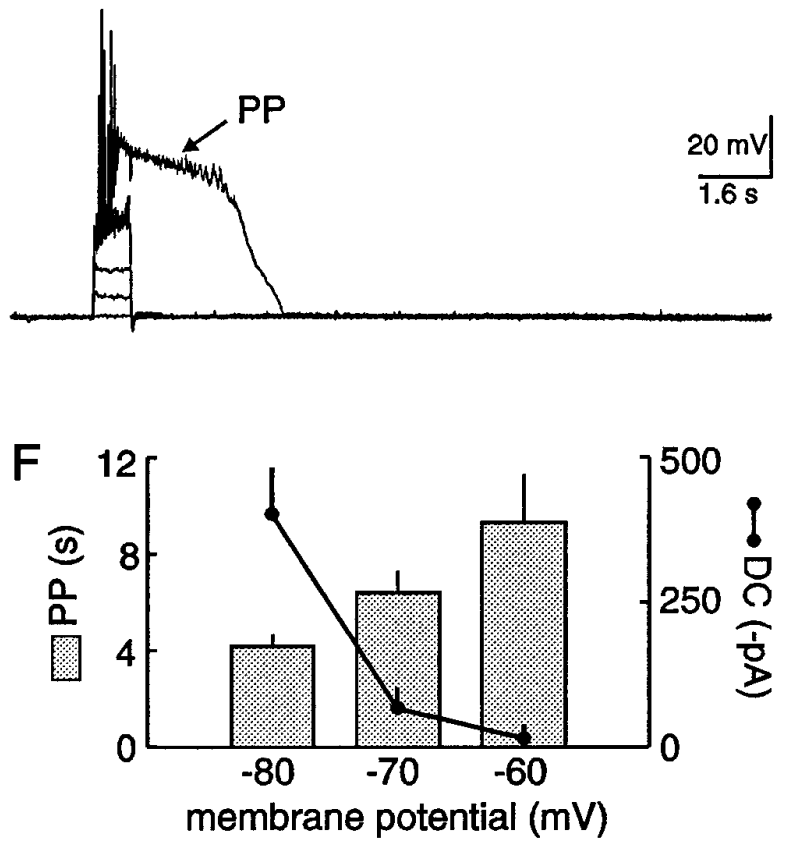

Figure 4. The amplitude of the sADP and the duration of the PP decreased with negative membrane potentials. $A$, Typical response of a hippocampal pyramidal neuron to hyperpolarizing and depolarizing current injection. Neither an sADP nor a PP was observed in the absence of cholinergic stimulation. The resting membrane potential of this pyramidal neuron was $-66 \mathrm{mV}$. B, In the presence of $20 \mu \mathrm{M}$ carbachol, the neuron depolarized to $-63 \mathrm{mV}$. After depolarizing current injection, both an SADP and a PP were evoked from a membrane potential of $-60 \mathrm{mV}$. $C-E$, Decreasing the membrane potential with negative DC current injection decreased the amplitude of the sADP. In contrast, the PP was still generated, however, the duration decreased with lowered membrane potentials. $F$, A plot illustrating the PP duration and negative DC current injection versus membrane potential. The data were tabulated from three neurons.

the sADP and PP could not be evoked, even if the amplitude and duration of current injection was increased.

To determine the HVA channel subtypes involved in sADP and PP genesis, blockers of either L- or N-type channels were included in the perfusate (Fig. 6). In the presence of $20 \mu \mathrm{M}$ carbachol, both a SADP and PP were evoked after intracellular current injection and spike firing. The addition of $10 \mu \mathrm{M}$ nimodipine, an L-type channel blocker, to the perfusate depressed the sADP and abolished the PP (Fig. $6 A ; n=4 / 4$ ). Although an sADP of $11 \pm 4 \mathrm{mV}$ (range $6-22 ; n=4$ ) was still observed, the amplitude of the depolarizing current had been increased twofold. Similarly, coapplication of $1 \mu \mathrm{M}$ $\omega$-conotoxin-GVIA, an N-type channel blocker, also depressed the sADP and abolished the PP (Fig. $6 B ; n=4 / 4$ ). As above, an sADP of $10 \pm 2 \mathrm{mV}$ (range $6-17 ; n=4$ ) was still observed, however, these stimuli were also increased twofold. The N-type channel blocker $\omega$-conotoxin-GVIA was coapplied with 0.1 $\mathrm{mg} / \mathrm{ml}$ cytochrome $\mathrm{C}$ to inhibit nonspecific binding. Cytochrome $\mathrm{C}$, however, had no measurable effect on either the sADP or PP (Fig. $6 B ; n=4$ ). Interestingly, neither nimodipine nor $\omega$-conotoxin-GVIA abolished the SADP, suggesting that both L- and $\mathrm{N}$-type channels participate in elevating intracellular $\mathrm{Ca}^{2+}\left(\left[\mathrm{Ca}^{2+}\right]_{\mathrm{i}}\right)$ to a critical level for PP genesis. These data, however, cannot rule out the minor involvement of other HVA $\mathrm{Ca}^{2+}$ channels in SADP and PP genesis.

Taken together, these data demonstrated that both $\mathrm{Na}^{+}$and $\mathrm{Ca}^{2+}$ influx was critical for sADP and PP genesis. Moreover, $\mathrm{Ca}^{2+}$ influx occurred via $\mathrm{HVA} \mathrm{Ca}^{2+}$ channels, predominantly of the $\mathrm{L}$ and $\mathrm{N}$ subtypes, whereas $\mathrm{Na}^{+}$influx occurred independently of TTX-sensitive channels.

\section{lonic mechanisms underlying the sADP and PP}

To elucidate whether $\mathrm{Ca}^{2+}$ influx functioned primarily as a charge carrier or as an intracellular messenger, $\left[\mathrm{Ca}^{2+}\right]_{\mathrm{i}}$ was chelated by 

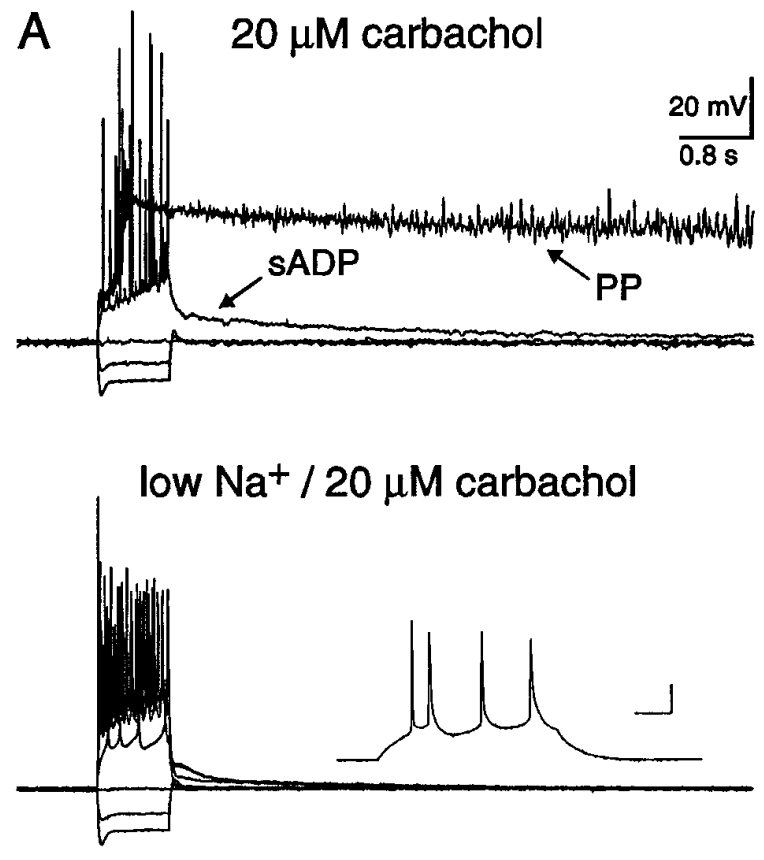

C

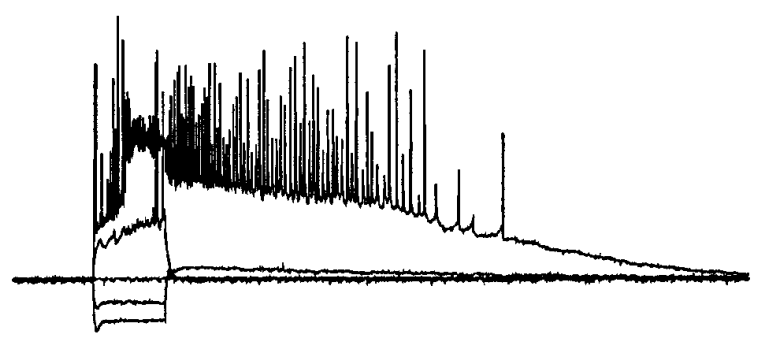

$+1.2 \mu \mathrm{M} T \mathrm{TX}$

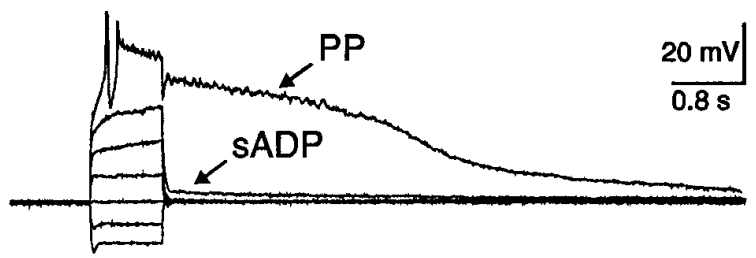

B $\quad 20 \mu \mathrm{M}$ carbachol

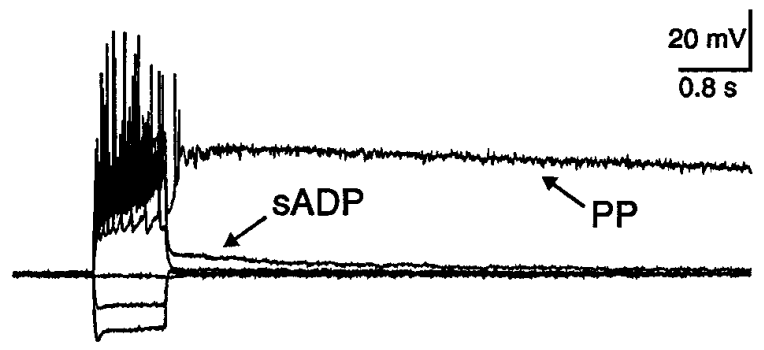

low $\mathrm{Ca}^{2+} / 20 \mu \mathrm{M}$ carbachol
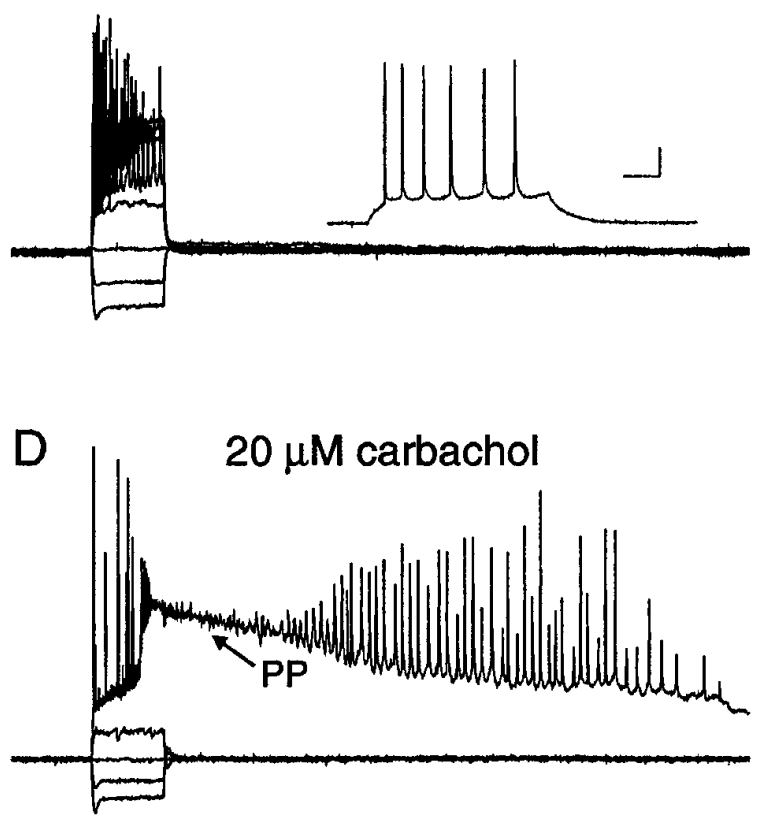

$+100 \mu \mathrm{M} \mathrm{Cd} 2+$

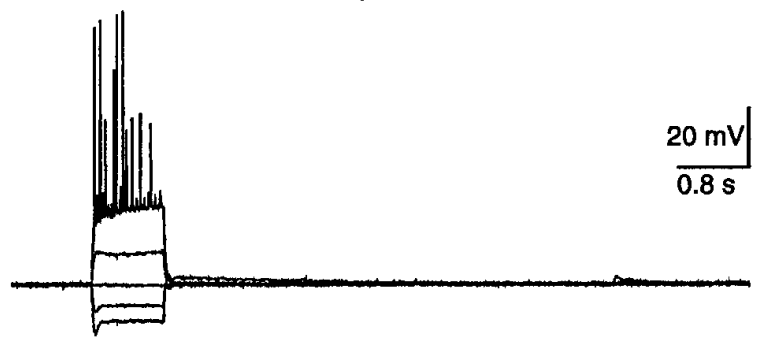

Figure 5. Both the sADP and PP were dependent on $\mathrm{Na}^{+}$influx, independent of TTX-sensitive channels and $\mathrm{Ca}^{2+}$ influx via $\mathrm{HVA}$ channels. $A$, In 20 $\mu \mathrm{M}$ carbachol, depolarizing current injection evoked both an sADP and a PP. Lowering external $\mathrm{Na}^{+}$from 152 to 26 mM reversibly depressed the sADP and abolished the PP, suggesting that $\mathrm{Na}^{+}$influx was required for these afterpotentials. The resting potentials before and after cholinergic stimulation were -68 and $-59 \mathrm{mV}$, respectively. The calibration bars in the inset represent $40 \mathrm{msec}$ and $20 \mathrm{mV}$. $B$, In a different pyramidal neuron, both the sADP and PP were evoked by intracellular current injection. Lowering external $\mathrm{Ca}^{2+}$ from 2 to $0.1 \mathrm{~mm}$ reversibly abolished both the sADP and PP. The concentration of $\mathrm{Mg}^{2+}$ was simultaneously increased from 2 to $10 \mathrm{~mm}$ to maintain divalent cation charge screening. This finding suggests that Ca ${ }^{2+}$ influx was also necessary for these potentials. The resting potentials of this neuron before and after cholinergic stimulation were -67 and $-60 \mathrm{mV}$, respectively. The calibration bars in the inset represent $40 \mathrm{msec}$ and $20 \mathrm{mV}$. C, In $20 \mu \mathrm{M}$ carbachol, an sADP and a PP were observed after evoked action potentials. Coapplication of $1.2 \mu \mathrm{M}$ TTX, a concentration sufficient to block action potentials, failed to depress either the sADP or the PP. Notice that the PP followed a slow regenerative potential, presumably $\mathrm{Ca}^{2+}$-dependent, whereas the sADP did not. Activation of voltage-dependent $\mathrm{Na}^{+}$channels, therefore, was not required for either of these afterpotentials. The resting membrane potentials before and after carbachol were -65 and $-62 \mathrm{mV}$, respectively. $D$, In carbachol, an sADP and a PP were elicited by intracellular current injection. Coapplication of $100 \mu \mathrm{M} \mathrm{Cd}{ }^{2+}$ abolished both the sADP and PP. Activation of $\mathrm{HVA} \mathrm{Ca}^{2+}$ channels, therefore, was necessary to evoke these potentials. The resting membrane potential in control was $-69 \mathrm{mV}$, whereas $20 \mu \mathrm{M}$ carbachol depolarized the membrane potential to $-62 \mathrm{mV}$. 

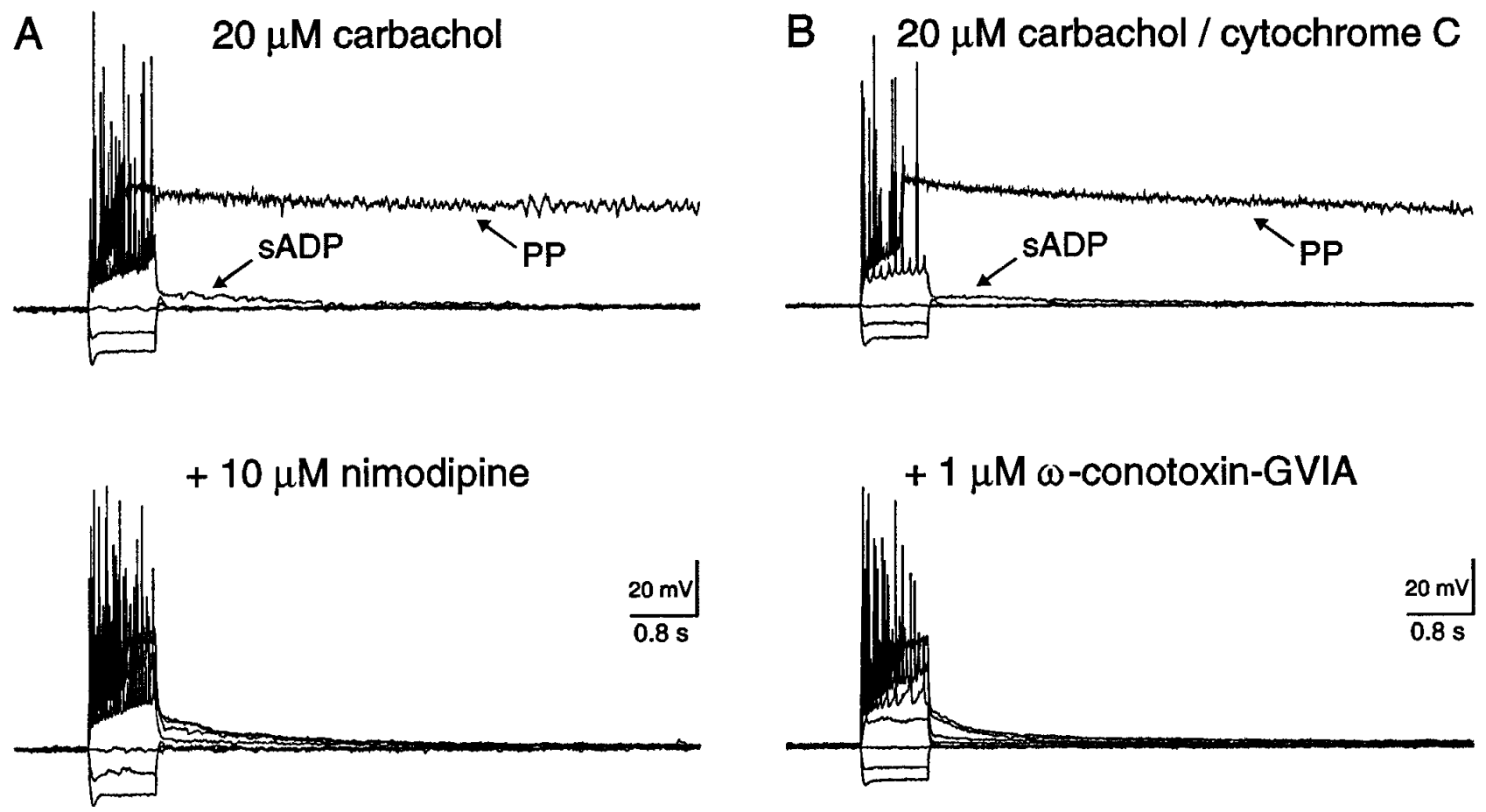

Figure 6. The sADP and $\mathrm{PP}$ required $\mathrm{Ca}^{2+}$ influx through $\mathrm{L}$ - and $\mathrm{N}$-type $\mathrm{Ca}^{2+}$ channels. $A$, In a CA1 pyramidal neuron, intracellular current injection revealed an SADP and a PP in the presence of $20 \mu \mathrm{M}$ carbachol. The resting membrane potentials before and after cholinergic stimulation were -64 and $-60 \mathrm{mV}$, respectively. The sADP was reduced and the PP could not be evoked after coapplication of the L-type channel blocker nimodipine. $B$, In another pyramidal neuron, both the cholinergic-dependent sADP and PP were also evoked by intracellular current injection. The resting membrane potentials before and after cholinergic stimulation were -66 and $-61 \mathrm{mV}$, respectively. Both the sADP and PP were reversibly depressed by coapplication of the N-type channel blocker $\omega$-conotoxin-GVIA.

inclusion of $10 \mathrm{~mm}$ bis(2-aminophenoxy)ethane- $N, N, N^{\prime}, N^{\prime}$-tetraacetic acid (BAPTA) in the pipette solution (Table 1). Application of $20 \mu \mathrm{M}$ carbachol not only failed to depolarize these BAPTA-containing neurons, but neither the sADP nor the PP were observed after action potential firing evoked by depolarizing current injection (Fig. $7 B ; n=4 / 4$ ). In the same slices, however, both the cholinergic-dependent SADP and PP were evoked in pyramidal neurons dialyzed with control intracellular solution (Fig. $7 A ; n=4 / 4$ ). These data demonstrate that elevations in $\left[\mathrm{Ca}^{2+}\right]_{\mathrm{i}}$ were critical for genesis of the sADP and PP. Hence, the primary role of $\mathrm{Ca}^{2+}$ influx was to serve as an intracellular messenger, not as a charge carrier.

The goal of the next set of experiments was to determine whether the sADP and PP could be evoked by maximizing $\mathrm{Ca}^{2+}$ influx via $\mathrm{K}^{+}$channel suppression. Two methods were used independently to suppress $\mathrm{K}^{+}$channels. First, external $\mathrm{K}^{+}$channel blockers $[10 \mathrm{mM}$ tetraethylammonium (TEA), $5 \mathrm{~mm}$ 4-aminopyridine (4-AP), $100 \mu \mathrm{M} \mathrm{Ba}{ }^{2+}$; Fig. 8A;n=9] were included in the perfusate, and when applied to pyramidal neurons, depolarized the membrane potential by $9 \pm 1 \mathrm{mV}$ (range 5-10; $n=9)$. Second, $40 \mathrm{~mm} \mathrm{Cs}^{+}$was included in the pipette solution $\left(\left[\mathrm{Cs}^{+}\right]_{\mathrm{i}}\right.$; Fig. $8 B$; Table $1 ; n=11$ ). Both conditions would independently increase $\mathrm{Ca}^{2+}$ influx, and yet neither the sADP nor the PP could be elicited from a membrane potential maintained at $-60 \mathrm{mV}$ with negative DC current injection. Even though $\mathrm{K}^{+}$ channels were suppressed, application of $20 \mu \mathrm{M}$ carbachol still depolarized the membrane potential by an additional $4 \pm 1 \mathrm{mV}$ (range 2-7; $n=17$ ) (Benson et al., 1988; Colino and Halliwell, 1993). In the presence of carbachol, both the sADP and PP were now easily evoked from a membrane potential of $-60 \mathrm{mV}$. These afterpotentials followed regenerative $\mathrm{Ca}^{2+}$ spikes and, as before, were reversibly depressed by reduction of extracellular $\mathrm{Na}^{+}$from 152 to $26 \mathrm{~mm}$ (Fig. $8 A, B ; n=17 / 17$ ). A small sADP, however, was still observed in low extracellular $\mathrm{Na}^{+}$with a maximal amplitude of $5 \pm 1 \mathrm{mV}$ (range $3-13 ; n=17$ ); however, the amplitude of the depolarizing current injection was twofold greater. Interestingly, the membrane potential of the PP measured at $0.2 \mathrm{sec}$ after cessation of the stimuli was $10 \mathrm{mV}$ more positive when $\mathrm{K}^{+}$ channels were suppressed $(-9 \pm 2 \mathrm{mV}$; range -21 to $3 ; n=17$; vs control $-19 \pm 1 \mathrm{mV})$. These experiments demonstrate that $\mathrm{Ca}^{2+}$ influx alone was not sufficient for sADP and PP genesis. Moreover, $\mathrm{Na}^{+}$was the main charge carrier underlying the sADP and $\mathrm{PP}$, whereas deactivation of a $\mathrm{K}^{+}$conductance by maintained $\mathrm{Ca}^{2+}$ influx was excluded as a contributing mechanism (Constanti and Bagetta, 1991; Constanti et al., 1993). Finally, the membrane potential of the PP in the presence of $\mathrm{K}^{+}$channel blockers $(-9$ $\mathrm{mV}$ ) was consistent with activation of a $\mathrm{Ca}^{2+}$-activated nonselective cation conductance with little contribution of concurrent outward conductances.

In the following experiments, the involvement of a $\mathrm{Na}^{+} / \mathrm{Ca}^{2+}$ exchanger was tested in two ways (Crépel et al., 1994). First, 50 $\mathrm{mm} \mathrm{LiCl}$ was substituted for equimolar $\mathrm{NaCl}$ in the extracellular solution (Fig. $9 A ; n=4$ ). Immediately after ion substitution, the membrane potential depolarized by $9 \pm 1 \mathrm{mV}$ (range $6-11 \mathrm{mV}$; $n=4$ ) corresponding to $\mathrm{Li}^{+}$-induced depression of the $\mathrm{Na}^{+} / \mathrm{K}^{+}$ ATPase (Glynn, 1993). Negative DC current was applied via the recording pipette $(-60 \pm 9 \mathrm{pA}$; range -80 to $-40 \mathrm{pA} ; n=4)$, however, to maintain the membrane potential at the same presubstitution level. Depolarizing current was then injected and, as described previously, both the SADP and PP were evoked after 


\section{A $1.1 \mathrm{mM}$ EGTA / $0.1 \mathrm{mM} \mathrm{Ca}{ }^{2+}$}
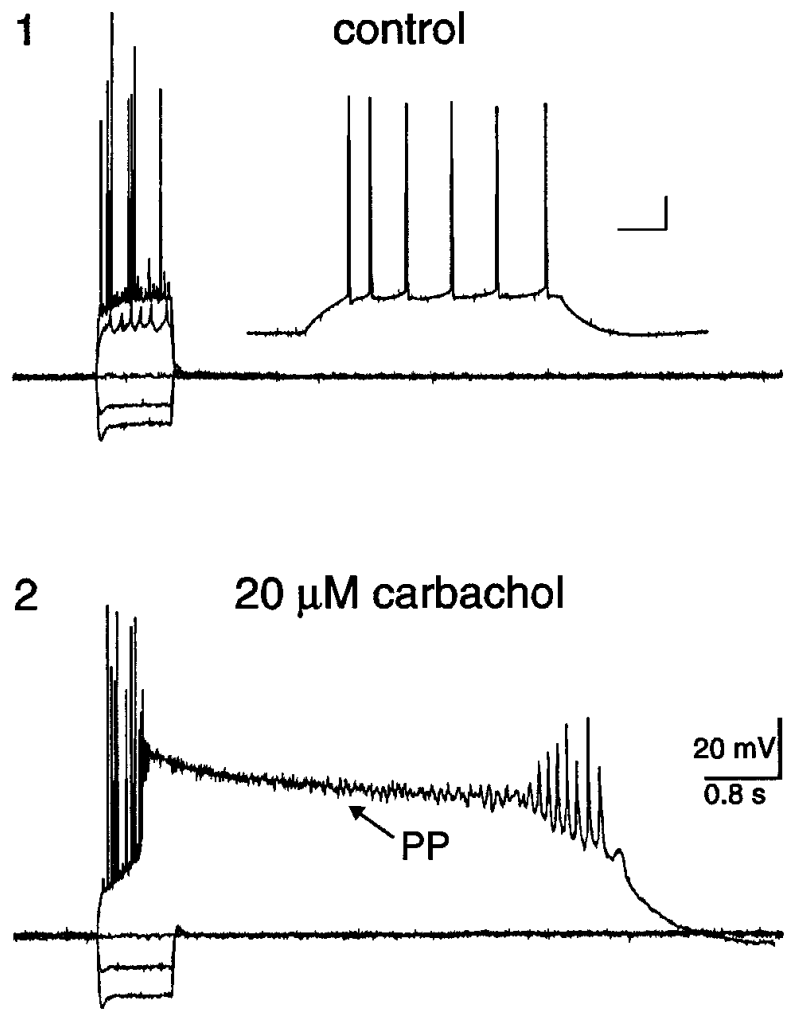

B $\quad 10 \mathrm{mM}$ BAPTA
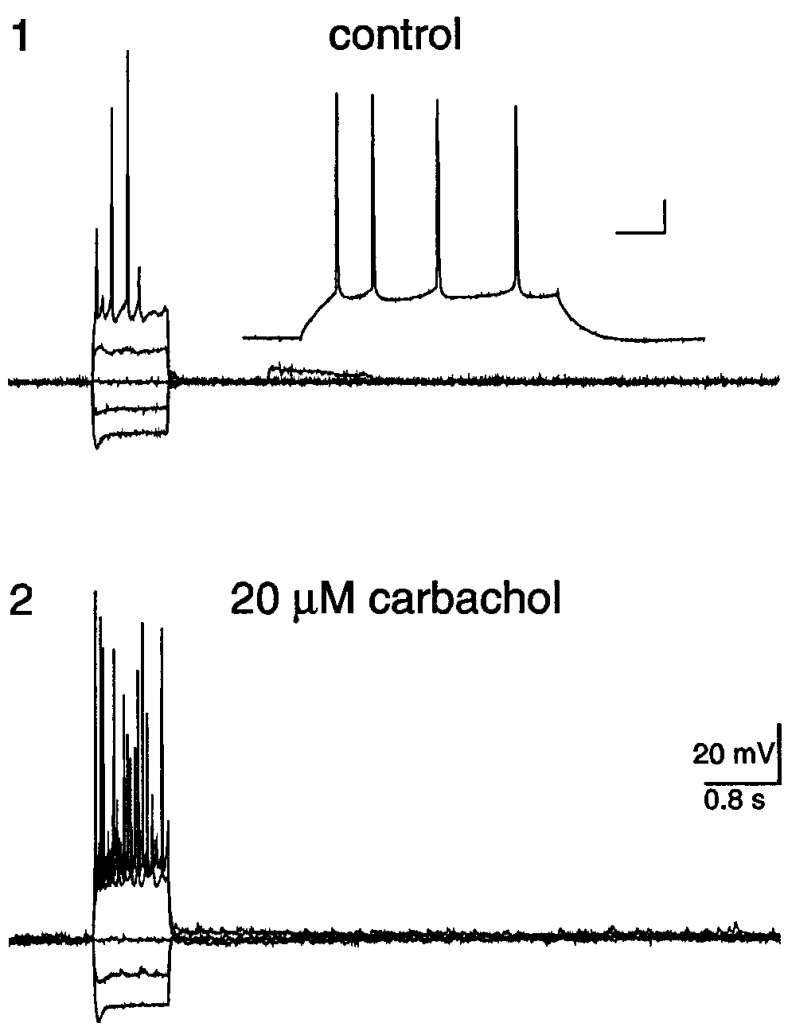

Figure 7. Both the sADP and PP were blocked by intracellular BAPTA. A, Typical responses of a hippocampal pyramidal neuron to hyperpolarizing and depolarizing current injection. Neither an SADP nor a PP was observed in the absence of cholinergic stimulation (A1). The calibration bars in the inset represent $40 \mathrm{msec}$ and $20 \mathrm{mV}$. In the presence of carbachol, however, depolarizing current injection evoked a long-lasting PP (A2). This pyramidal neuron was loaded with pipette solution containing $1.1 \mathrm{~mm} \mathrm{EGTA}$ and $0.1 \mathrm{mM} \mathrm{Ca}^{2+}$ and, thus, intracellular $\mathrm{Ca}^{2+}$ was bufferred to $\sim 16 \mathrm{~nm}$. $B$, A different pyramidal neuron, recorded from the same slice as the neuron illustrated in $A$, loaded with $10 \mathrm{mM}$ BAPTA. In control aCSF, neither an sADP nor a PP was observed (B1). The calibration bars in the inset represent $40 \mathrm{msec}$ and $20 \mathrm{mV}$. In the presence of carbachol, neither an sADP nor a PP could be evoked, suggesting that elevated $\left[\mathrm{Ca}^{2+}\right]_{\mathrm{i}}$ was necessary for these potentials $(B 2)$.

spike firing in all neurons tested $(n=4 / 4)$. Because the $\mathrm{Na}^{+} / \mathrm{Ca}^{2+}$ exchanger is also depressed by $\mathrm{Li}^{+}$(Reuter and Porzig, 1995), this experiment implies that the $\mathrm{Na}^{+} / \mathrm{Ca}^{2+}$ exchanger played little, if any, role in genesis of the SADP and PP. An alternative explanation favored by this experiment is the $\mathrm{Ca}^{2+}$-activated nonselective cation channel that is permeable to $\mathrm{Li}^{+}$(Yellen, 1982). In the second experiment, spike firing elicited by depolarizing current injection evoked both the cholinergic-dependent SADP and PP. The bath temperature was then lowered from 35 to $25^{\circ} \mathrm{C}$, and action potential firing was elicited as described previously (Fig. $9 B ; n=3)$. In all cases, a decrease of $10^{\circ} \mathrm{C}$ did not depress either the sADP or the PP. Because the $\mathrm{Na}^{+} / \mathrm{Ca}^{2+}$ exchanger is extremely temperature-sensitive (Kimura and Reeves, 1979; see Crépel et al., 1994), this second set of experiments also implies that the $\mathrm{Na}^{+} / \mathrm{Ca}^{2+}$ exchanger played a negligible role in genesis of the sADP and PP. Interestingly, if the bath temperature was lowered to $21-23^{\circ} \mathrm{C}$, the PP could not be elicited (data not shown; $n=3)$.

Taken together, these experiments indicate that both the sADP and $\mathrm{PP}$ require three events: cholinergic stimulation, an elevation in $\left[\mathrm{Ca}^{2+}\right]_{\mathrm{i}}$ via $\mathrm{HVA} \mathrm{Ca}^{2+}$ channels (L- and N-type), and activation of the $\mathrm{Ca}^{2+}$-activated nonselective cation conductance.

\section{Effects of individual $\mathrm{K}^{+}$channel blockers on the sADP and PP}

Although the sADP and PP could not be unmasked by $\mathrm{K}^{+}$ channel suppression, once elicited, these waveforms are likely to be modulated by concurrent outward $\mathrm{K}^{+}$conductances. The effects of individual $\mathrm{K}^{+}$channel blockers, therefore, were tested on the sADP and PP to determine whether individual $\mathrm{K}^{+}$conductances influenced the shape and/or duration of the afterpotential waveforms. In the absence of carbachol, the addition of $10 \mathrm{~mm}$ TEA to the perfusate resulted in an initial $5 \pm 2 \mathrm{mV}$ (range 2-7 $\mathrm{mV} ; n=3$ ) depolarization of the membrane potential. When the membrane potential was stable, spike firing elicited by intracellular current injection revealed a brief PP, probably mediated by HVA Ca ${ }^{2+}$ channels activated by action potential firing (Fig. 10A; $n=3 / 3$ ) (Bourque et al., 1986). After cessation of the stimuli, neither an SADP nor a PP was observed. In a different pyramidal neuron, both the cholinergic-dependent SADP and PP were easily evoked after action potential firing. Coapplication of $10 \mathrm{~mm}$ TEA, however, reduced the amplitude of the SADP and the duration of the PP (Fig. $10 A ; n=4 / 4$ ). The duration of the PP was reduced from $11.6 \pm 4.1 \mathrm{sec}$ (range $10-21.4 ; n=4$ ) in carbachol to $6.9 \pm$ $2 \mathrm{sec}$ (range $1.3-10.4 ; n=4$ ) in the presence of TEA. Further- 
A TTX / TEA / 4-AP / $\mathrm{Ba}^{2+}$

1
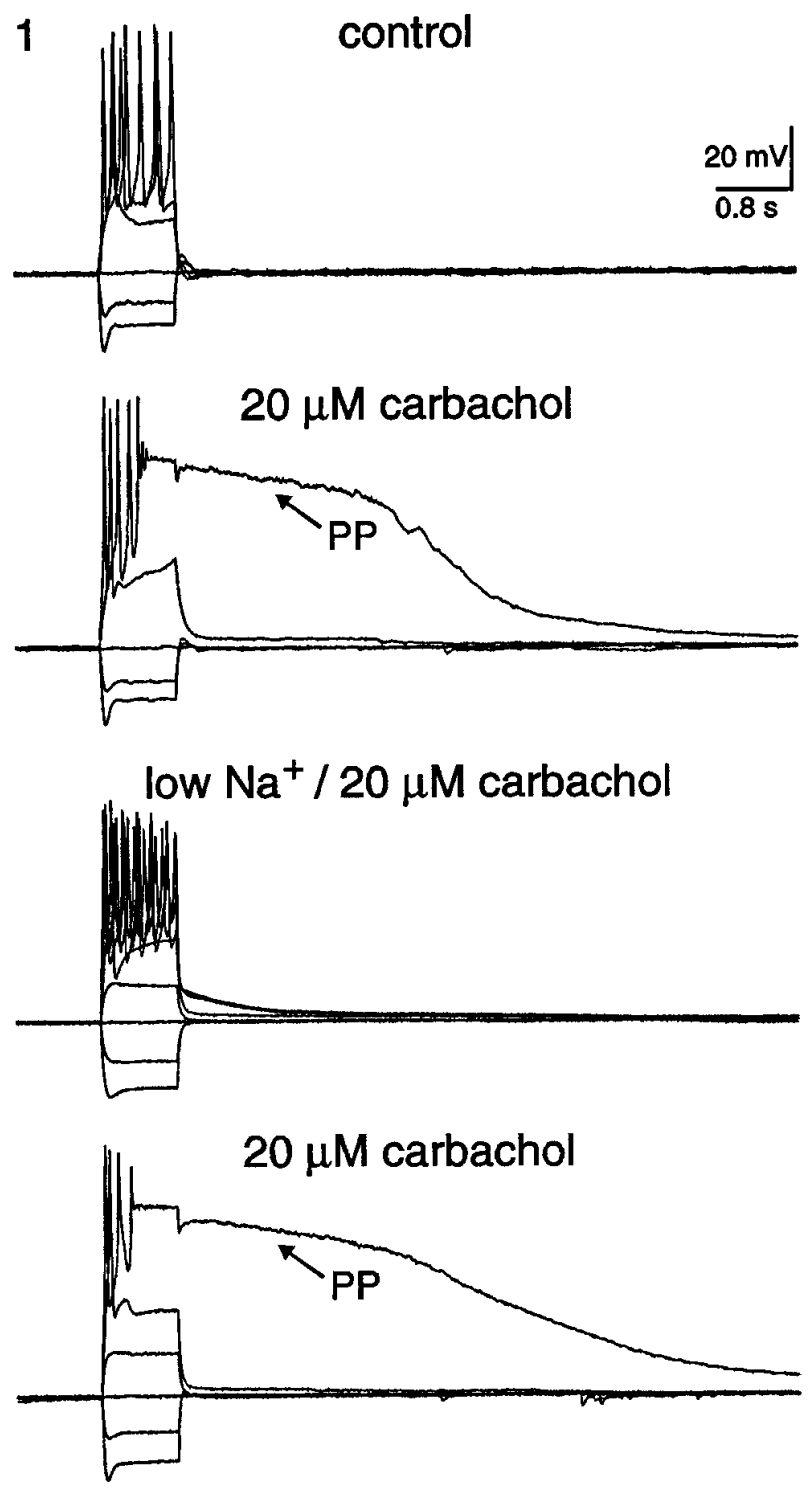

2

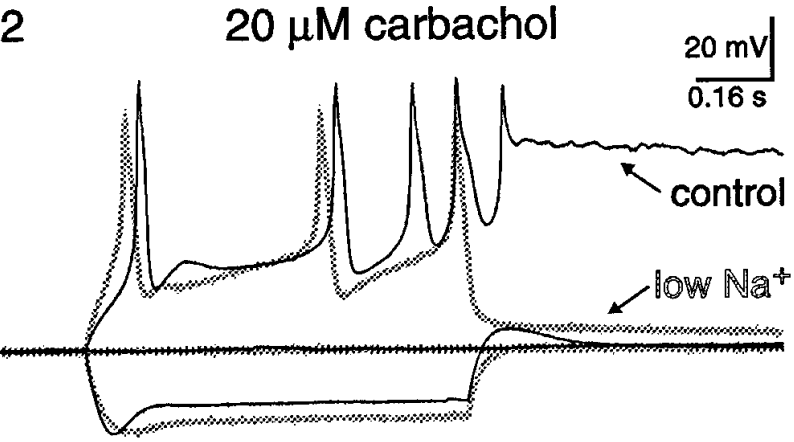

B $\quad$ TTX $/\left[\mathrm{Cs}^{+}\right]_{\mathrm{i}}$
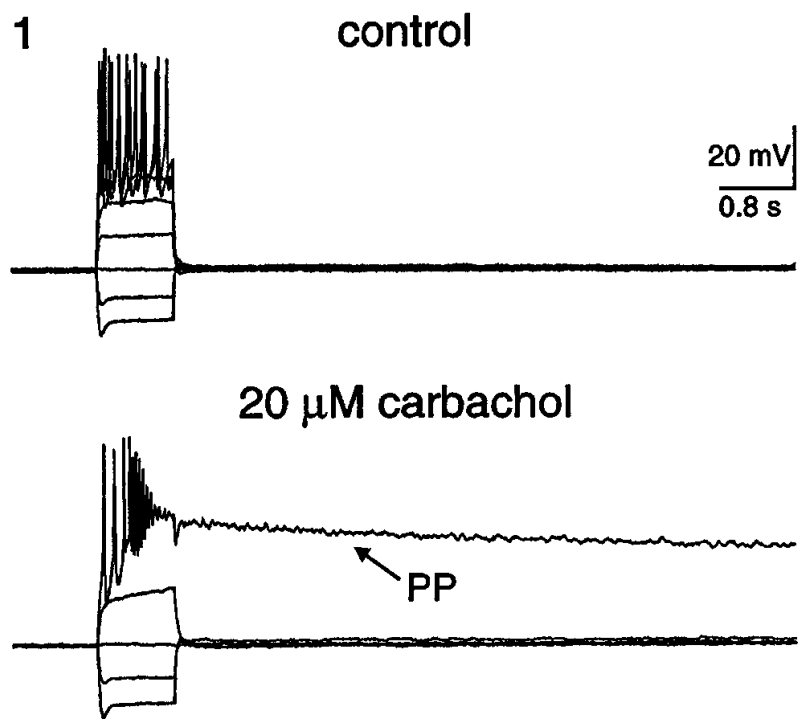

low $\mathrm{Na}^{+} / 20 \mu \mathrm{M}$ carbachol

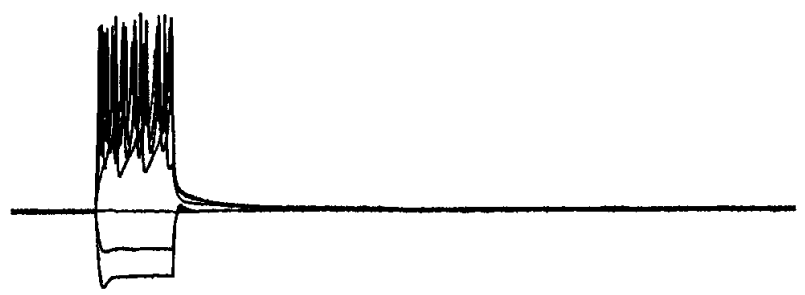

$20 \mu \mathrm{M}$ carbachol

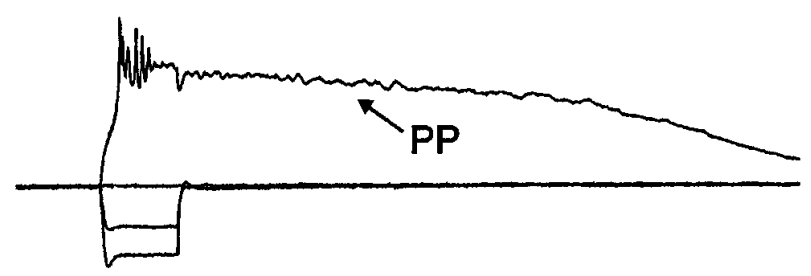

2

$20 \mu \mathrm{M}$ carbachol

$20 \mathrm{mV}$

$0.16 \mathrm{~s}$

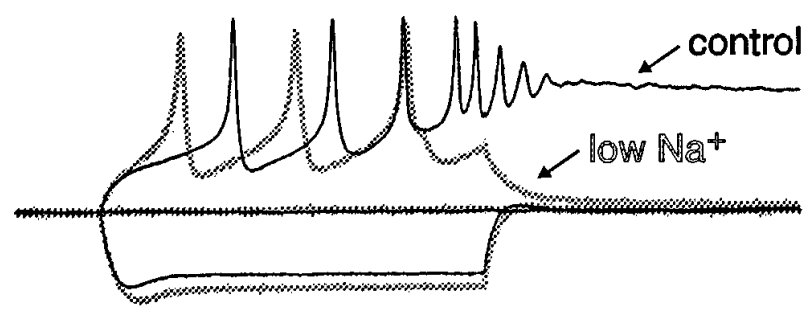

Figure 8. Blockers of $\mathrm{K}^{+}$channels failed to unmask either the sADP or the PP in the absence of cholinergic stimulation. $A$, The sADP and PP were not observed after application of $1.2 \mu \mathrm{M}$ TTX and $\mathrm{K}^{+}$channel blockers (10 mM TEA, $5 \mathrm{mM} 4-\mathrm{AP}, 100 \mu \mathrm{M} \mathrm{Ba}^{2+}$ ). Cholinergic stimulation, however, revealed a PP that was reversibly depressed by lowering $\mathrm{Na}^{+}$from 152 to $26 \mathrm{mM}$ in the external media $(A 1)$. Notice that robust $\mathrm{Ca}^{2+}$ spikes remained in low Na ${ }^{+}$, whereas the PP was reversibly depressed $(A 2)$. $B$, In addition, neither the sADP nor the PP was observed in pyramidal neurons loaded with 40 mM intracellular $\mathrm{Cs}^{+}$and bathed in $1.2 \mu \mathrm{M}$ TTX. As above, cholinergic stimulation revealed a PP that was reversibly depressed by lowering Na ${ }^{+}$in the external media (B1). In this example, robust $\mathrm{Ca}^{2+}$ spikes also remained in low $\mathrm{Na}^{+}$, whereas the PP was reversibly depressed (B2). 
A

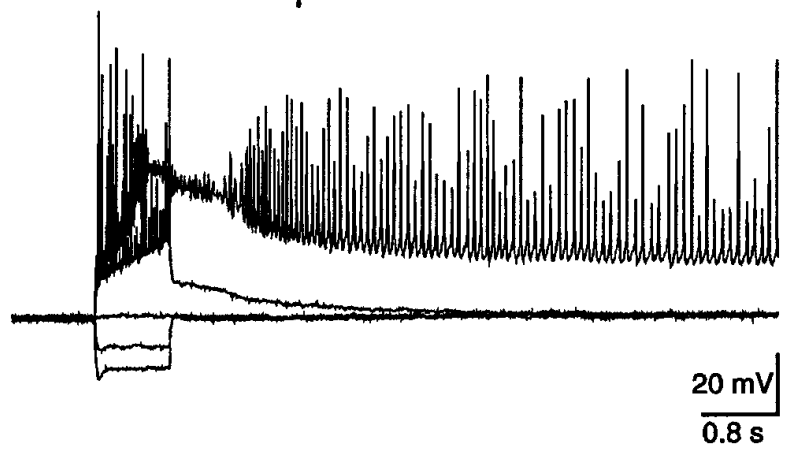

$50 \mathrm{mM} \mathrm{Li}+/ 20 \mu \mathrm{M}$ carbachol

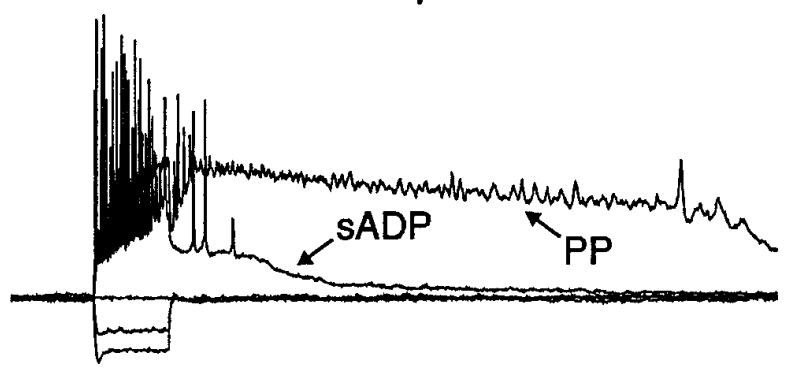

B $\quad 20 \mu \mathrm{M}$ carbachol $/ 35^{\circ} \mathrm{C}$
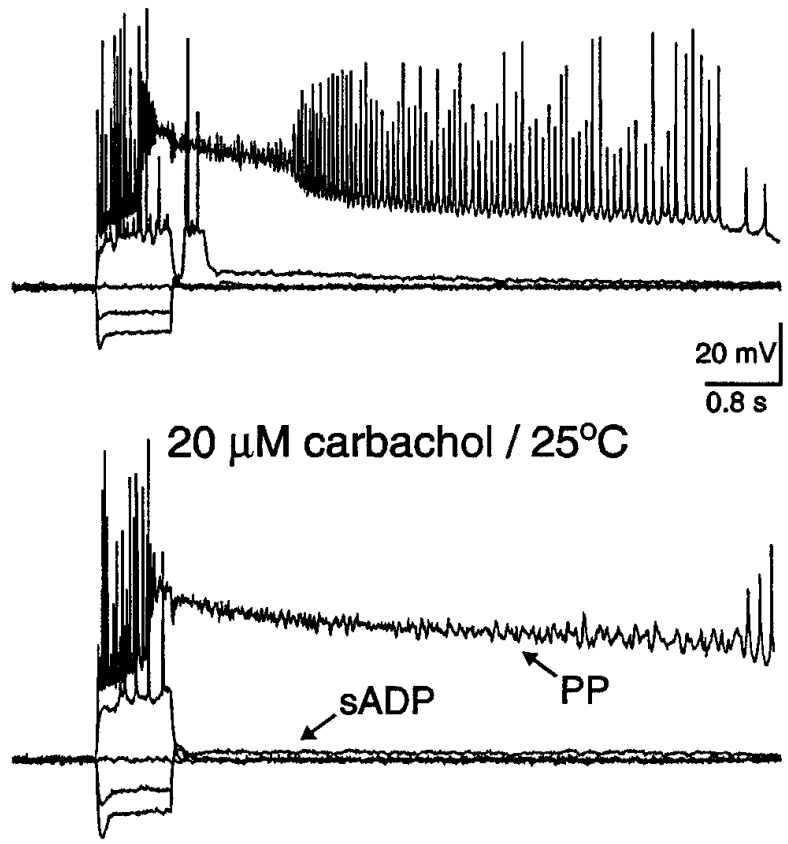

Figure 9. The sADP and PP were independent of a $\mathrm{Na}^{+} / \mathrm{Ca}^{2+}$ exchanger. $A$, Intracellular current injection revealed an $\mathrm{sADP}$ and a PP in the presence of $20 \mu \mathrm{M}$ carbachol. The resting membrane potentials before and after cholinergic stimulation were -70 and $-62 \mathrm{mV}$, respectively. Both the sADP and PP were still observed after substitution of $50 \mathrm{mM} \mathrm{Li}^{+}$for equimolar $\mathrm{Na}^{+}$in the external media. After $\mathrm{Li}^{+}$substitution, the membrane depolarized an additional $9 \mathrm{mV}$; however, negative DC current was injected to maintain the membrane potential at the presubstitution value. $B$, In a different neuron, intracellular current injection also revealed an SADP and a PP in the presence of $20 \mu \mathrm{M}$ carbachol. The resting membrane potentials before and after cholinergic stimulation were -66 and $-61 \mathrm{mV}$, respectively. Both the sADP and PP were still observed after a reduction in bath temperature from 35 to $25^{\circ} \mathrm{C}$. The neuron depolarized after temperature reduction, however, negative DC current was injected to maintain the membrane potential at the same value as at $35^{\circ} \mathrm{C}$.

more, the membrane potential of the PP measured at $0.2 \mathrm{sec}$ after cessation of the stimuli was increased from $-15 \pm 3 \mathrm{mV}$ (range -20 to $-9 ; n=4$ ) in carbachol to $-8 \pm 3 \mathrm{mV}$ (range -4 to 0 ) in the presence of TEA. Because TEA effectively increased $\mathrm{Ca}^{2+}$ influx via $\mathrm{K}^{+}$channel depression, it seems reasonable to conclude that TEA inhibited the $\mathrm{Ca}^{2+}$-activated nonselective cation channel directly (see Crépel et al., 1994).

In separate experiments, the addition of $5 \mathrm{~mm} 4-\mathrm{AP}$ to the perfusate, in the absence of carbachol, resulted in a $3 \pm 1 \mathrm{mV}$ (range $1-4 \mathrm{mV} ; n=3$ ) depolarization of the membrane potential. This $\mathrm{K}^{+}$channel blocker also increased $\mathrm{Ca}^{2+}$ influx, but instead of a single PP, which was observed after TEA perfusion, a transient potential followed each action potential (Fig. 10B; $n=3$ ). After a burst of evoked action potentials, only a brief afterpotential was observed in 4-AP. In a different pyramidal neuron, a PP was evoked in the presence of $20 \mu \mathrm{M}$ carbachol that was slightly prolonged by coapplication of 4-AP (Fig. 10B; $n=3 / 3$ ). The duration of the PP was $11.3 \pm 0.9 \mathrm{sec}$ (range 9.7-12.8; $n=3$ ) in carbachol versus $14.3 \pm 1.1 \mathrm{sec}$ (range $11.4-15 ; n=3$ ) in 4-AP. In addition, the membrane potential of the PP measured at $0.2 \mathrm{sec}$ after cessation of the stimuli was increased from $-20 \pm 2 \mathrm{mV}$ (range -22 to $-17 ; n=3$ ) in carbachol to $-14 \pm 1 \mathrm{mV}$ (range -17 to -13$)$ in the presence of $4-\mathrm{AP}$. The small increase in duration may reflect increased $\mathrm{Ca}^{2+}$ influx stimulated by $\mathrm{K}^{+}$ channel suppression.

In the absence of carbachol, the addition of $100 \mu \mathrm{M} \mathrm{Ba}^{2+}$ to the perfusate resulted in a $4 \pm 1 \mathrm{mV}$ (range $2-5 ; n=3$ ) depolarization of the membrane potential. This $\mathrm{K}^{+}$channel blocker increased $\mathrm{Ca}^{2+}$ influx as evidenced by increased spike broadening
(Fig. 10C; $n=3$ ) (Bourque et al., 1986). At this concentration, however, it is unlikely that $\mathrm{Ba}^{2+}$ permeated the HVA $\mathrm{Ca}^{2+}$ channels, because $\mathrm{Ba}^{2+}$ has a much lower binding affinity within the pore and therefore is repelled out of the channel by $\mathrm{Ca}^{2+}$ (Hess and Tsien, 1984). Even with increased $\mathrm{Ca}^{2+}$ influx, neither an sADP nor a PP was evoked after current injection. In another pyramidal neuron, an SADP and a PP were observed after current injection in the presence of $20 \mu \mathrm{M}$ carbachol. Coapplication of 100 $\mu \mathrm{M} \mathrm{Ba}^{2+}$ greatly prolonged the PP duration (Fig. 10C; $n=3 / 3$ ). In carbachol, the average duration of the PP was $8.8 \pm 2.1 \mathrm{sec}$ (range 5.9-13.7; $n=3$ ), whereas in $\mathrm{Ba}^{2+}$ the duration increased to 17.2 $\pm 3.1 \mathrm{sec}$ (range 13.6-22.9; $n=3$ ). In addition, the membrane potential of the PP measured at $0.2 \mathrm{sec}$ after cessation of the stimuli was increased from $-17 \pm 1 \mathrm{mV}$ (range -20 to $-16 ; n=$ 3 ) in carbachol to $-12 \pm 1 \mathrm{mV}$ (range -14 to -10 ) in the presence of $\mathrm{Ba}^{2+}$. These data imply that $\mathrm{a} \mathrm{Ba}^{2+}$-sensitive conductance contributed to the shape of the PP waveform. A likely candidate expressed in hippocampal pyramidal neurons that opposes prolonged depolarizations and is $\mathrm{Ba}^{2+}$-sensitive is $I_{\mathrm{M}}$ (Halliwell and Adams, 1982). Additional $\mathrm{K}^{+}$channels are, however, also suppressed by this divalent cation.

In the absence of carbachol, the simultaneous addition of $\mathrm{Ca}^{2+}$-activated $\mathrm{K}^{+}$channel blockers [100 $\mathrm{nm}$ iberiotoxin (ITX), $100 \mathrm{~nm}$ apamin] to the perfusate depolarized the neurons by $3 \pm$ 1 (range $0-4 ; n=4$ ) and completely blocked the afterhyperpolarization after each action potential. In the presence of these blockers, however, neither the sADP nor the PP could be evoked (data not shown; $n=4 / 4$ ). In different pyramidal neurons, both ITX and apamin failed to affect either the SADP or PP observed 

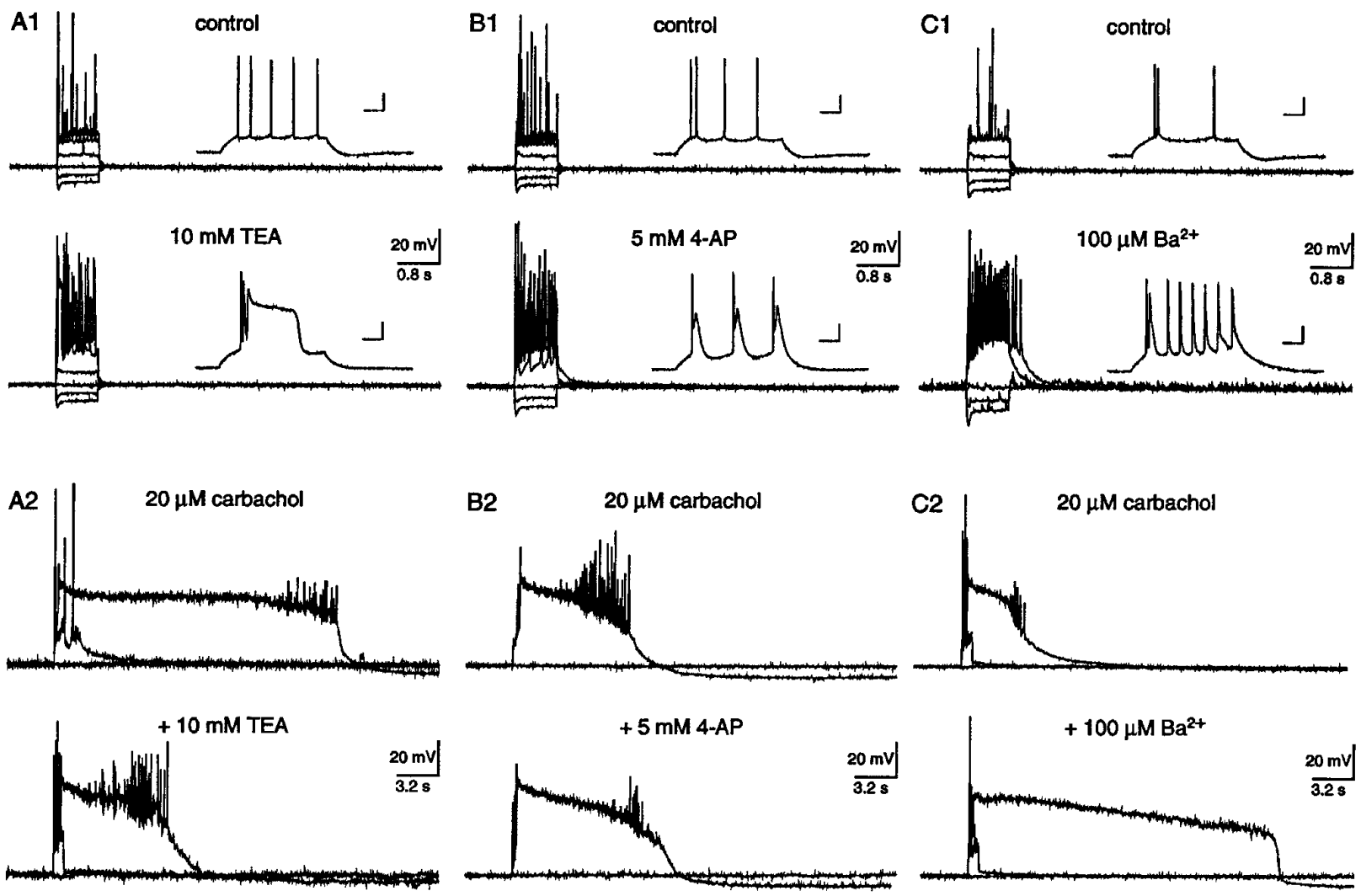

Figure 10. Individual $\mathrm{K}^{+}$channel blockers modulate the PP waveform. $A$, Action potential firing in the presence of $10 \mathrm{~mm}$ TEA resulted in a brief plateau potential that was presumably $\mathrm{Ca}^{2+}$-dependent $(A 1)$. Neither an sADP nor a PP was observed after cessation of the depolarizing stimulus. The calibration bars in the inset represent $40 \mathrm{msec}$ and $20 \mathrm{mV}$. In a different neuron, both the sADP and PP were observed in the presence of $20 \mu \mathrm{M}$ carbachol $(A 2)$. Coapplication of $10 \mathrm{~mm}$ TEA abolished the sADP and decreased the duration of the PP. $B$, In the presence of $5 \mathrm{~mm} 4$-AP, individual action potentials activated brief afterdepolarizations that presumably were $\mathrm{Ca}^{2+}$-dependent (B1). After cessation of the depolarizing current stimuli, a brief afterpotential was commonly observed. Neither the sADP nor the PP was observed. The calibration bars in the inset represent $40 \mathrm{msec}$ and $20 \mathrm{mV}$. In another neuron, a PP was evoked in the presence of $20 \mu \mathrm{M}$ carbachol (B2). Coapplication of $5 \mathrm{~mm} 4$-AP slightly prolonged the PP. $C$, Application of $100 \mu \mathrm{M} \mathrm{Ba}^{2+}$ to the perfusate resulted in a brief afterpotential and subsequent spike broadening $(\mathrm{Cl})$. Brief afterpotentials were also observed after depolarizing current stimuli, however, neither the sADP nor the PP was evoked. In the presence of $20 \mu \mathrm{M}$ carbachol, a different neuron exhibited an sADP and a PP after cessation of stimuli (C2). Coapplication of $100 \mu \mathrm{M} \mathrm{Ba}^{2+}$ to the perfusate increased the PP duration.

after carbachol application $(n=3 / 3)$. These experiments indicate that $\mathrm{Ca}^{2+}$-activated $\mathrm{K}^{+}$conductances did not shape either the sADP or PP waveforms.

Taken together, these experiments again illustrate that although $\mathrm{Ca}^{2+}$ influx was increased via $\mathrm{K}^{+}$channel depression, the sADP and PP required cholinergic stimulation. In addition, TEA may have an inhibitory affect on the $\mathrm{Ca}^{2+}$-activated nonselective cation channel, whereas a $\mathrm{Ba}^{2+}$-sensitive current (e.g., $I_{\mathrm{M}}$ ) was important for determining the duration of the PP waveform.

\section{Conductance changes accompanying the PP}

In the final experiments, changes in $R_{\mathrm{IN}}$ were examined during the PP by injection of low-amplitude current pulses $(-50 \mathrm{pA} ; 0.2 \mathrm{sec}$; $5 \mathrm{~Hz}$; Fig. 11). In all neurons examined, the $R_{\mathrm{IN}}$ decreased during the PP by $81 \pm 2 \%$ (range $71-87 ; n=16$ ), measured within $2 \mathrm{sec}$ after cessation of the depolarizing current stimuli (Fig. 11A). In the presence of TTX and $\mathrm{K}^{+}$channel blockers, the $R_{\mathrm{IN}}$ measured during the PP also decreased by $80 \pm 3 \%$ (range 75-84; $n=3$; Fig. $11 B$ ). Because similar changes in $R_{\mathrm{IN}}$ were obtained in the absence and presence of both TTX and $\mathrm{K}^{+}$channel blockers, the contributions of slow $\mathrm{Na}^{+}$oscillations and $\mathrm{K}^{+}$channel activation were minimal in analysis of conductance changes immediately after cessation of stimuli. In all cases, a reproducible pattern was observed, in which the $R_{\mathrm{IN}}$ observed immediately after cessation of the depolarizing stimuli gradually diminished during the PP. Even though the $R_{\mathrm{IN}}$ increased significantly during the PP, only a minor change in membrane potential was observed (Fig. 11C). Finally, injection of large-amplitude current pulses of long duration $(-0.4 \mathrm{nA} ; 1 \mathrm{sec})$ failed to terminate the PP (Fig. 11D; $n=4 / 4)$.

\section{DISCUSSION}

In this study, we report a cholinergic-induced SADP and PP recorded from hippocampal CA1 pyramidal neurons with the whole-cell patch-clamp technique. We propose that the PP represents a novel regenerative event involving the interplay between HVA $\mathrm{Ca}^{2+}$ channels (L- and N-type) and the $\mathrm{Ca}^{2+}$-activated nonselective cation conductance. These ionic mechanisms may contribute significantly to ictal depolarizations observed during temporal-lobe seizures of the partial-complex subtype (Lothman et al., 1991).

Both the SADP and PP were depressed by removal of either $\mathrm{Na}^{+}$or $\mathrm{Ca}^{2+}$ from the external media, and blocked by either extracellular $\mathrm{Cd}^{2+}$ or chelation of $\left[\mathrm{Ca}^{2+}\right]_{\mathrm{i}}$ by inclusion of BAPTA in the intracellular solution. Moreover, the sADP was depressed and the PP was abolished by either the L-type channel blocker, nimodipine, or the N-type channel blocker $\omega$-conotoxin-GVIA. 
A

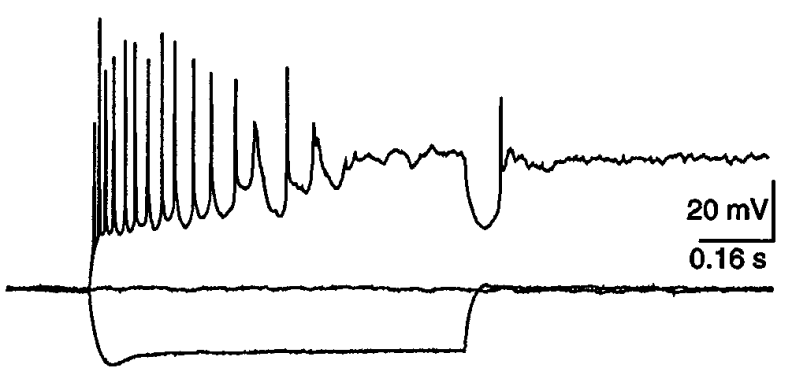

$20 \mu \mathrm{M}$ carbachol

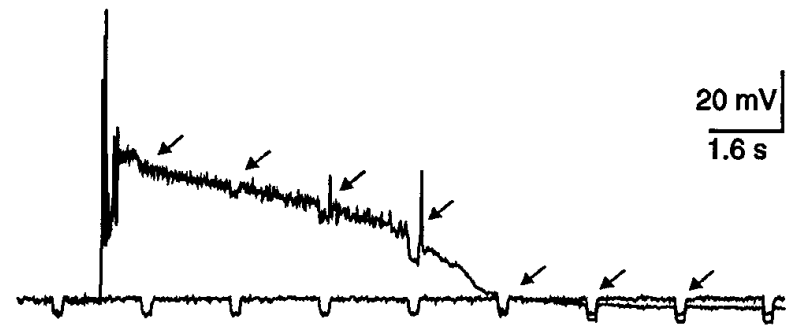

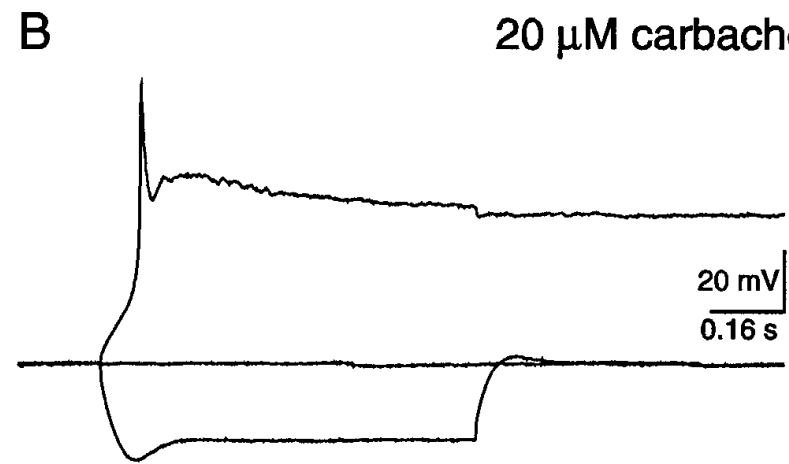

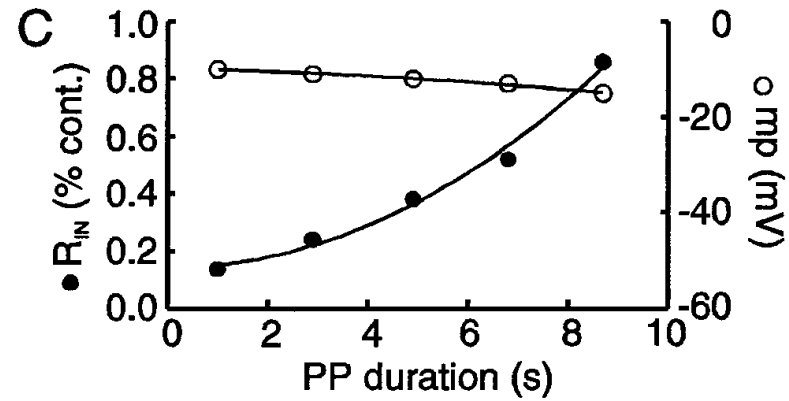

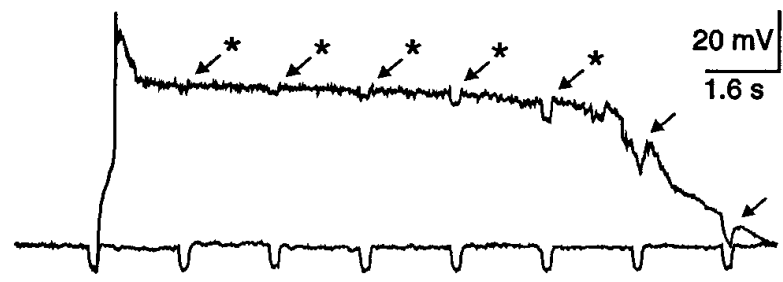

D $20 \mu \mathrm{M}$ carbachol / TTX/ $\mathrm{K}^{+}$blockers

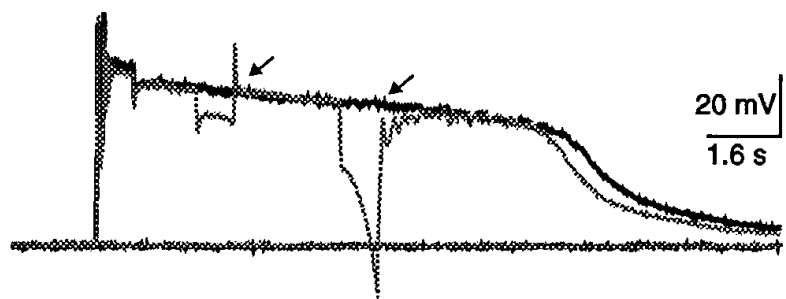

Figure 11. The PP was associated with a large $R_{\mathrm{IN}}$ decrease and could not be terminated by hyperpolarizing pulses. $A$, Cholinergic-dependent PPs illustrated on two time scales. In the latter, brief current injection $(-50 \mathrm{pA} ; 0.2 \mathrm{sec} ; 0.5 \mathrm{~Hz})$ demonstrated a large decreased $R_{\mathrm{IN}} . B$, PPs in the presence of carbachol, TTX, and $\mathrm{K}^{+}$channel blockers (10 mM TEA, $\left.5 \mathrm{~mm} 4-\mathrm{AP}, 100 \mu \mathrm{M} \mathrm{Ba}{ }^{2+}\right)$. Under these conditions, brief current injection confirmed an $R_{\mathrm{IN}}$ decrease in the absence of slow $\mathrm{Na}^{+}$oscillations and suppression of $\mathrm{K}^{+}$channels. $C$, A graph depicting the decreased $R_{\mathrm{IN}}$ relative to control obtained at the resting potential, versus duration of the PP. In the same graph, membrane potential was also plotted versus PP duration. Both $R_{\mathrm{IN}}$ and membrane potential values were obtained from the neuron illustrated in $B\left({ }^{*}\right)$. Notice that the change in membrane potential was minimal, whereas the increase in $R_{\mathrm{IN}}$ was significant. $D$, Two superimposed PPs evoked from a CA1 pyramidal neuron. In the broken trace, hyperpolarizing current injection $(-0.4 \mathrm{nA}$; $0.8 \mathrm{sec}$ ) failed to terminate the PP.

Superfusion of TTX at a concentration sufficient to block fast action potentials, however, did not suppress either the SADP or PP. These data imply that both the sADP and PP rely on elevations in $\left[\mathrm{Ca}^{2+}\right]_{\mathrm{i}}$ via $\mathrm{HVA} \mathrm{Ca}{ }^{2+}$ channels (L- and $\mathrm{N}$-type) and $\mathrm{Na}^{+}$ influx independent of TTX-sensitive channels.

One possible mechanism contributing to the sADP and PP described here is the $\mathrm{Na}^{+} / \mathrm{Ca}^{2+}$ exchanger (Friedman et al., 1992). Our experiments, however, do not support a role for this mechanism. First, equimolar substitution of extracellular $\mathrm{Na}^{+}$ with $50 \mathrm{mM} \mathrm{Li}^{+}$did not affect either the sADP or the PP. The $\mathrm{Na}^{+} / \mathrm{Ca}^{2+}$ exchanger does not use $\mathrm{Li}^{+}$as a charge carrier (Kimura et al., 1987; Reuter and Porzig, 1995); however, the $\mathrm{Ca}^{2+}$-activated nonselective cation channel is permeable to $\mathrm{Li}^{+}$ (Yellen, 1982). Second, lowering the temperature from 35 to $25^{\circ} \mathrm{C}$ also did not affect either the sADP or the PP (see Crépel et al.,
1994). Because the $\mathrm{Na}^{+} / \mathrm{Ca}^{2+}$ exchanger is highly temperaturesensitive (Kimura and Reeves, 1979), this latter experiment also suggests that this mechanism plays a negligible role in sADP and PP genesis. Another possible mechanism that may have contributed to the SADP and PP is deactivation of a $\mathrm{K}^{+}$conductance by maintained $\mathrm{Ca}^{2+}$ influx (Constanti and Bagetta, 1991; Constanti et al., 1993). This mechanism was also ruled out by our experiments because both the sADP and the PP were observed in the presence of either extracellular $\mathrm{K}^{+}$channel blockers or $\left[\mathrm{Cs}^{+}\right]_{\mathrm{i}}$. Furthermore, an increased conductance was observed during both the sADP and PP, which is not consistent with this mechanism (Constanti and Bagetta, 1991). Based on our experiments, a $\mathrm{Ca}^{2+}$-activated nonselective cation conductance is the prime candidate for sADP genesis (Schwindt et al., 1988; Hasuo et al., 1990; Caeser et al., 1993). The PP, however, relied not only on the 
$\mathrm{Ca}^{2+}$-activated nonselective cation conductance, but also on prolonged activation of HVA Ca ${ }^{2+}$ channels (Blitzer et al., 1991). After $\mathrm{Ca}^{2+}$ was elevated to a critical level by spike firing, the $\mathrm{Ca}^{2+}$-activated nonselective cation channel was sufficiently activated to depolarize the membrane potential positive enough to sustain $\mathrm{Ca}^{2+}$ influx, and the regenerative potential was initiated. Hence, the sADP represents a weak depolarization mediated by residual $\left[\mathrm{Ca}^{2+}\right]_{i}$, whereas the PP represents a novel regenerative event relying on continual activation of both $\mathrm{HVA} \mathrm{Ca}^{2+}$ channels and the $\mathrm{Ca}^{2+}$-activated nonselective cation conductance.

A major question is whether the $\mathrm{Ca}^{2+}$-activated nonselective cation conductance was directly enhanced by carbachol or simply unmasked by cholinergic-induced suppression of $\mathrm{K}^{+}$conductances (Caesar et al., 1993). Our data indicate that the $\mathrm{Ca}^{2+}$. activated nonselective cation conductance was directly enhanced by cholinergic stimulation. In the presence of either $\mathrm{K}^{+}$channel blockers or $\left[\mathrm{Cs}^{+}\right]_{\mathrm{i}}$, neither the sADP nor the PP was observed. The SADP and PP were only elicited after carbachol was added to the perfusate. Because HVA $\mathrm{Ca}^{2+}$ channels are depressed by cholinergic stimulation (Toselli and Lux, 1989), the $\mathrm{Ca}^{2+}$. activated nonselective cation channel must have been augmented by carbachol. Cholinergic-induced depression of $\mathrm{K}^{+}$channels would, however, facilitate genesis of the SADP and PP by increasing the net inward current. Moreover, because neither the sADP nor the PP was observed with $\mathrm{K}^{+}$channel depression, the $\mathrm{Ca}^{2+}$ activated nonselective cation channel must have a low openchannel probability in the absence of cholinergic stimulation.

Previous studies have shown that PPs can be generated by either voltage-activated $\mathrm{Ca}^{2+}$ or $\mathrm{Na}^{+}$channels. PPs generated by $\mathrm{Ca}^{2+}$ channels alone, however, are observed only when $\mathrm{K}^{+}$ channel blockers are present, intracellular $\mathrm{Ca}^{2+}$ is chelated, and/or $\mathrm{Ba}^{2+}$ ions are used as the charge carriers (Llinas and Yarom, 1981; Bourque et al., 1986). PPs generated solely by voltage-activated $\mathrm{Ca}^{2+}$ channels are depressed by muscarinic agonists (Misgeld et al., 1986). This effect is consistent with voltage-clamp studies demonstrating cholinergic-induced depression of HVA $\mathrm{Ca}^{2+}$ channels (Toselli and Lux, 1989). Alternatively, fast-inactivating $\mathrm{Na}^{+}$channels may gate in a bimodal manner, whereby bursts of channel openings are prolonged (Taylor, 1993). In hippocampal pyramidal neurons, the role of persistent $\mathrm{Na}^{+}$channel openings in generating PPs is unclear, because these events have been observed only in 0 $\mathrm{Ca}^{2+}$ external media (Leung and Yim, 1991; García-Muñoz et al., 1993; Segal, 1994). PPs generated by these $\mathrm{Na}^{+}$channels are identified by their sensitivity to the specific channel blocker TTX. In contrast to the above mechanisms, the sADP and PP described here were evoked in physiological solutions, requiring only cholinergic stimulation. The expression of PPs in intact tissue, therefore, could occur as a result of burst firing and activation of the cholinergic system.

The $\mathrm{Ca}^{2+}$-activated nonselective cation conductance implicated in this study is present in a broad range of cell types (Partridge and Swandulla, 1988) and is distinct from voltagegated cation channels. For example, voltage-gated cation channels have been described in a variety of neuronal cell types (Hoehn et al., 1993; Alzheimer, 1994) and participate in afterpotential genesis after spike repolarization (Penington and Kelly, 1993). These depolarizing afterpotentials are not sensitive to $\left[\mathrm{Ca}^{2+}\right]_{\mathrm{i}}$, are only milliseconds in duration, and mediate burst firing at rapid frequencies (Deisz, 1996). Hence, the depolarizing afterpotentials mediated by voltage-activated cat- ion channels are clearly distinguishable from the SADP and PP described in this paper.

Based on our findings, the sADP represents an afterpotential due to the $\mathrm{Ca}^{2+}$-activated nonselective cation conductance activated by $\mathrm{Ca}^{2+}$ influx via HVA channels. The PP, however, represents a novel regenerative event involving the interplay between $\mathrm{HVA} \mathrm{Ca}^{2+}$ channels and the $\mathrm{Ca}^{2+}$-activated nonselective cation conductance. This interplay between channels may occur at a distal dendritic site because both a $\mathrm{Ca}^{2+}$. sensitive inward current (Benson et al., 1988; Colino and Halliwell, 1993) and HVA Ca ${ }^{2+}$ channels (L-type, Westenbroek et al., 1990; Magee and Johnston, 1995; N-type, Jones et al., 1989; Mills et al., 1994) have been localized to dendritic processes. Dendritically located currents may be one reason why the PP has not been reported previously; for example, the PP may have been masked by a large somatic current shunt produced by microelectrode impalement (Spruston and Johnston, 1992; Staley et al., 1992). In addition, many studies using whole-cell patch-clamp techniques have either chelated $\left[\mathrm{Ca}^{2+}\right]_{i}$ or worked at room temperature, where the PP was not observed. Under our experimental conditions, the ability to evoke the sADP and PP was both reliable and reproducible.

The sADP and PP described here involved intrinsic mechanisms directly modulated by cholinergic stimulation. These included enhancement of the $\mathrm{Ca}^{2+}$-activated nonselective cation conductance and depression of several $\mathrm{K}^{+}$conductances. It is unlikely that other neurotransmitters (e.g., glutamate) or synaptic interactions played a significant role in this study because both the sADP and PP were observed in TTX. Moreover, thin slices (150 $\mu \mathrm{m}$ ) were commonly used where synaptic connections and recurrent collaterals were minimal. Although other neurotransmitters and synaptic interactions were presumably not involved in SADP and PP genesis in this study, they likely play a significant physiological role. For example, previous work in cortical neurons has demonstrated a cholinergic-sensitive slow inward conductance potentiated by low-frequency synaptic stimulation of white matter (Andrade, 1991). It is therefore conceivable that a PP could also be evoked during synaptic stimulation. For instance, cholinergic stimulation elevates intradendritic $\mathrm{Ca}^{2+}$ accumulation in hippocampal pyramidal neurons during repetitive firing (Müller and Connor, 1991) and enhances $\mathrm{Ca}^{2+}$ influx via postsynaptic NMDA receptors (Markram and Segal, 1992; Segal, 1992). This elevation in dendritic $\left[\mathrm{Ca}^{2+}\right]_{\mathrm{i}}$ could activate the $\mathrm{Ca}^{2+}$-activated nonselective cation conductance. Depolarization of the membrane would then activate $\mathrm{HVA} \mathrm{Ca}^{2+}$ channels, and a regenerative PP could be initiated. Similar mechanisms may underlie long-duration rhythmic bursts observed after either cholinergic or metabotropic stimulation of hippocampal slices (Bianchi and Wong, 1994, 1995). In our hands, stimulation of metabotropic glutamate receptors with trans-(I)-1-amino-1,3-cyclopentanedicarboxylic acid also resulted in SADP and PP generation (our unpublished observations). Interestingly, both cholinergic and metabotropic glutamate receptors are linked to phospholipase C via G-proteins, suggesting a common final pathway.

\section{Functional significance}

Cholinergic agents are effective in generating hippocampal seizures both in vivo and in vitro (Lothman et al., 1991; Wasterlain et al., 1993). In the hippocampal slice preparation, these same analogs generate prolonged depolarizations (Bianchi and Wong, 1994) and exacerbate ictal depolarizations observed during high $\mathrm{K}^{+}$-induced seizures (Yaari and Jensen, 1989). In this paper, we 
have identified a novel regenerative PP involving the interplay between $\mathrm{HVA} \mathrm{Ca}^{2+}$ channels and the $\mathrm{Ca}^{2+}$-activated nonselective cation conductance, and have also presented evidence that this latter conductance was directly enhanced by cholinergic stimulation. Because this PP has properties reminiscent of ictal depolarizations observed during cholinergic-induced seizures, it seems reasonable to conclude that these mechanisms could play a central role in hippocampal epileptogenesis.

\section{REFERENCES}

Alonso A, Llinas RR (1989) Subthreshold $\mathrm{Na}^{+}$-dependent theta-like rhythmicity in stellate cells of entorhinal cortex layer II. Nature 342:175-177.

Alzheimer C (1994) A novel voltage-dependent cation current in rat neocortical neurones. J Physiol (Lond) 479:199-205.

Andrade R (1991) Cell excitation enhances muscarinic cholinergic responses in rat association cortex. Brain Res 548:81-93.

Behrends JC, Bruggencate G (1993) Cholinergic modulation of synaptic inhibition in the guinea pig hippocampus in vitro: excitation of GABAergic interneurons and inhibition of GABA-release. J Neurophysiol 69:626-629.

Benson DM, Blitzer RD, Landau EM (1988) An analysis of the depolarization produced in guinea-pig hippocampus by cholinergic receptor stimulation. J Physiol (Lond) 404:479-496.

Bernardo LS, Prince DA (1982) Cholinergic excitation of mammalian hippocampal pyramidal cells. Brain Res 249:315-331.

Bianchi R, Wong RKS (1994) Carbachol-induced synchronized rhythmic bursts in CA3 neurons of guinea pig hippocampus in vitro. J Neurophysiol 72:131-138.

Bianchi R, Wong RKS (1995) Excitatory synaptic potentials dependent on metabotropic glutamate receptor activation in guinea pig hippocampal pyramidal neurons. J Physiol (Lond) 487:663-676.

Bland BH (1986) The physiology and pharmacology of hippocampal formation theta rhythms. Prog Neurobiol 26:1-54.

Blanton MG, Lo Turco JJ, Kriegstein AR (1989) Whole cell recording from neurons in slices of reptilian and mammalian cerebral cortex. J Neurosci Methods 30:203-210.

Blitzer RD, Gil O, Omri G, Landau E (1991) Nifedipine blocks calciumdependent cholinergic depolarization in the guinea pig hippocampus. Brain Res 542:293-299.

Bourque CW, Brown DA, Renaud LP (1986) Barium ions induce prolonged plateau depolarizations in neurosecretory neurones of the adult rat supraoptic nucleus. J Physiol (Lond) 375:573-586.

Brown KT, Flaming DG (1992) Advanced micropipette techniques for cell physiology, pp 176-203. New York: Wiley.

Caeser M, Brown DA, Gähwiler BH, Knöpfel T (1993) Characterization of a calcium-dependent current generating a slow afterdepolarization of CA3 pyramidal cells in rat hippocampal slice cultures. Eur J Neurosci 5:560-569.

Colino A, Halliwell JV (1993) Carbachol potentiates Q current and activates a calcium-dependent non-specific conductance in rat hippocampus in vitro. Eur J Neurosci 5:1198-1209.

Constanti A, Bagetta G (1991) Muscarinic receptor activation induces a prolonged post-stimulus afterdepolarization with a conductance decrease in guinea-pig olfactory cortex neurones in vitro. Neurosci Lett 131:27-32.

Constanti A, Bagetta G, Libri V (1993) Persistent muscarinic excitation in guinea pig olfactory cortex neurons: involvement of a slow poststimulus afterdepolarizing current. Neuroscience 56:887-904.

Crépel V, Aniksztejn L, Ben-Ari Y, Hammond C (1994) Glutamate metabotropic receptors increase a $\mathrm{Ca}^{2+}$-activated nonspecific cationic current in CA1 hippocampal neurons. J Neurophysiol 72:1561-1569.

Deisz RA (1996) A tetrodotoxin-insensitive sodium current initiates burst firing of neocortical neurons. Neuroscience 70:341-351.

Edwards FA, Konnerth A, Sakmann B, Takahashi T (1989) A thin slice preparation for patch clamp recordings from neurons of the mammalian central nervous system. Pfügers Arch 414:600-612.

Fraser DD, MacVicar BA (1991) Low-threshold transient $\mathrm{Ca}^{2+}$ current in lacunosum-moleculare interneurons: kinetics and modulation by neurotransmitters. J Neurosci 11:2812-2820.

Fraser DD, MacVicar BA (1995) Ionic mechanisms underlying the cholinergic-dependent plateau potentials in hippocampal CA1 pyramidal neurons. Soc Neurosci Abstr 25:32.
Friedman A, Arens J, Heinemann U, Gutnick MJ (1992) Slow depolarizing afterpotentials in neocortical neurons are sodium and calcium dependent. Neurosci Lett 135:13-17.

Gähwiler BH (1984) Facilitation by acetylcholine of tetrodotoxinresistant spikes in rat hippocampal pyramidal cells. Neuroscience 11:381-388.

García-Muñoz A, Barrio LC, Buno W (1993) Membrane potential oscillations in CA1 hippocampal pyramidal neurons in vitro: intrinsic rhythms and fluctuations entrained by sinusoidal injected current. Exp Brain Res 97:325-333.

Glynn IM (1993) All hands to sodium pump. J Physiol (Lond) 462:1-30.

Halliwell JV (1990) Physiological mechanisms of cholinergic action in the hippocampus. Prog Brain Res 84:255-272.

Halliwell JV, Adams PR (1982) Voltage-clamp analysis of muscarinic excitation in hippocampal neurons. Brain Res 250:71-92.

Hasuo H, Gallagher JP (1990) Facilitatory action of muscarine on the slow afterdepolarization of rat dorsolateral septal nucleus neurons in vitro. Neurosci Lett 112:234-238.

Hasuo H, Phelan KD, Twery MJ, Gallagher JP (1990) A calciumdependent afterdepolarization recorded in rat dorsolateral septal nucleus neurons in vitro. J Neurophysiol 64:1838-1846.

Hess P, Tsien RW (1984) Mechanism of ion permeation through calcium channels. Nature 309:453-456.

Hille BH (1984) Ionic channels of excitable membranes. Sunderland, MA: Sinauer.

Hoehn K, Watson TWJ, MacVicar BA (1993) A novel tetrodotoxininsensitive, slow sodium current in striatal and hippocampal neurons. Neuron 10:543-552.

Jones OT, Kunze DL, Angelides KJ (1989) Localization and mobility of $\omega$-conotoxin-sensitive $\mathrm{Ca}^{2+}$ channels in hippocampal CA1 neurons. Science 244:1189-1193.

Kimura JE, Reeves H (1979) The effect of temperature on the asymmetrical charge movement in squid giant axons. J Physiol (Lond) 289:479-500.

Kimura J, Miyamae S, Noma A (1987) Identification of a sodium-calcium exchange current in single ventricular cells of guinea-pig. J Physiol (Lond) 384:199-222.

Konopacki J, Bland BH, MacIver MB, Roth SH (1987) Cholinergic theta rhythm in transected hippocampal slices: independent CA1 and dentate generators. Brain Res 417:399-407.

Krnjević K (1993) Central cholinergic mechanisms and function. Prog Brain Res 98:285-292.

Leung LS, Yim CYC (1991) Intrinsic membrane potential oscillations in hippocampal neurons in vitro. Brain Res 553:261-274.

Llinas R, Yarom Y (1981) Properties and distribution of ionic conductances generating electroresponsiveness of mammalian inferior olivary neurones in vitro. J Physiol (Lond) 315:569-584.

Lothman EW, Bertram EH, Stringer JL (1991) Functional anatomy of hippocampal seizures. Prog Neurobiol 37:1-82.

MacVicar BA (1985) Depolarizing prepotentials are $\mathrm{Na}^{+}$dependent in CA1 pyramidal neurons. Brain Res 333:378-381.

MacVicar BA, Tse FWY (1989) Local neuronal circuitry underlying cholinergic rhythmical slow activity in CA3 area of rat hippocampal slices. J Physiol (Lond) 417:197-212.

Madison DV, Malenka RC, Nicoll RA (1987) Voltage clamp analysis of cholinergic action in the hippocampus. J Neurosci 7:733-741.

Magee JC, Johnston D (1995) Synaptic activation of voltage-gated channels in the dendrites of hippocampal pyramidal neurons. Science 268:301-304.

Markram H, Segal M (1992) The inositol 1,4,5-triphosphate pathway mediates cholinergic potentiation of rat hippocampal neuronal responses to NMDA. J Physiol (Lond) 447:513-533.

McCormick DA (1993) Actions of acetylcholine in the cerebral cortex and thalamus and implications for function. Prog Brain Res 98:303-308.

McCormick DA, Prince DA (1986) Mechanisms of action of acetylcholine in the guinea-pig cerebral cortex in vitro. J Physiol (Lond) 375:169-194.

Mills LR, Niesen CE, So AP, Carlen PL, Spigelman I, Jones OT (1994) $\mathrm{N}$-type $\mathrm{Ca}^{2+}$ channels are located on somata, dendrites, and a subpopulation of dendritic spines on live hippocampal pyramidal neurons. J Neurosci 14:6815-6824.

Misgeld U, Calabresi P, Dodt HU (1986) Muscarinic modulation of calcium dependent plateau potentials in rat neostriatal neurons. Pflügers Arch 407:482-487. 
Müller W, Connor JA (1991) Cholinergic input uncouples $\mathrm{Ca}^{2+}$ changes from $\mathrm{K}^{+}$conductance activation and amplifies intradendritic $\mathrm{Ca}^{2+}$ changes in hippocampal neurons. Neuron 6:901-905.

Müller W, Misgeld U, Heinemann U (1988) Carbachol effects on hippocampal neurons in vitro: dependence on the rate of rise of carbachol tissue concentration. Exp Brain Res 72:287-298.

Nakajima Y, Nakajima S, Leonard RJ, Yamaguchi K (1986) Acetylcholine raises excitability by inhibiting the fast transient potassium current in cultured hippocampal neurons. Proc Natl Acad Sci USA 83:3022-3026.

Partridge LD, Swandulla D (1988) $\mathrm{Ca}^{2+}$-activated non-specific cation channels. Trends Neurosci 11:69-72.

Penington NJ, Kelly JS (1993) Ionic dependence of a slow inward tail current in rat dorsal raphe neurones. J Physiol (Lond) 464:33-48.

Pitler TA, Alger BE (1992) Cholinergic excitation of GABAergic interneurons in the rat hippocampal slices. J Physiol (Lond) 450:127-142.

Reuter H, Porzig H (1995) Localization and functional significance of the $\mathrm{Na}^{+} / \mathrm{Ca}^{2+}$ exchanger in presynaptic boutons of hippocampal cells in culture. Neuron 15:1077-1084.

Schwindt PC, Spain WJ, Foehring RC, Chubb MC, Crill WE (1988) Slow conductances in neurons from cat sensorimotor cortex in vitro and their role in slow excitability changes. J Neurophysiol 59:450-467.

Segal M (1992) Acetylcholine enhances NMDA-evoked calcium rise in hippocampal neurons. Brain Res 587:83-87.

Segal MM (1994) Endogenous bursts underlie seizurelike activity in solitary excitatory hippocampal neurons in microcultures. J Neurophysiol 72:1874-1884.

Shen KZ, North RA (1992) Muscarine increases cation conductance and decreases potassium conductance in rat locus coeruleus neurones. J Physiol (Lond) 455:471-485.

Shen Y, Specht SM, De Saint Ghislain I, Li R (1994) The hippocampus: a biological model for studying learning and memory. Prog Neurobiol 44:485-496.

Spruston N, Johnston D (1992) Perforated patch-clamp analysis of the passive membrane properties of three classes of hippocampal neurons. J Neurophysiol 67:508-529.
Stabel J, Ficker E, Heinemann U (1992) Young CA1 pyramidal cells of rats, but not dentate gyrus granule cells, express a delayed inward rectifying current with properties of $\mathrm{I}_{\mathrm{O}}$. Neurosci Lett 135:231-234.

Staley KJ, Otis TS, Mody I (1992) Membrane properties of dentate gyrus granule cells: comparison of sharp microelectrodes and whole-cell recordings. J Neurophysiol 67:1346-1358.

Taylor CP (1993) $\mathrm{Na}^{+}$currents that fail to inactivate. Trends Neurosci 16:455-460.

Toselli M, Lux HD (1989) Opposing effects of acetylcholine on the two classes of voltage-dependent calcium channels in hippocampal neurons. In: Central cholinergic synaptic transmission (Frotscher M, Misgeld U, eds), pp 97-103. Birkhäuser, Basel.

Vanderwolf $\mathrm{CH}$ (1988) Cerebral activity and behavior: control by central cholinergic and serotonergic systems. Int Rev Neurobiol 30:225-340.

Wainer BH, Steininger TL, Roback JD, Burke-Watson MA, Mufson EJ, Kordower J (1993) Ascending cholinergic pathways: functional organization and implications for disease models. Prog Brain Res 98:9-30.

Wasterlain CG, Fujikawa DG, Penix L, Sankar R (1993) Pathophysiological mechanisms of brain damage from status epilepticus. Epilepsia 34:S37-S53.

Westenbroek RE, Ahlijanian MK, Catterall WA (1990) Clustering of L-type $\mathrm{Ca}^{2+}$ channels at the base of major dendrites in hippocampal pyramidal neurons. Nature 347:281-284.

Williams S, Samulack DD, Beaulieu C, Lacaille JC (1994) Membrane properties and synaptic responses of interneurons located near the stratum lacunosum-moleculare/radiatum border of area CA1 in wholecell recordings from rat hippocampal slices. J Neurophysiol 71:2217-2235.

Yaari Y, Jensen MS (1989) Cholinergic modulation of hippocampal epileptic activity in vitro. In: Central cholinergic synaptic transmission (Frotscher M, Misgeld U, eds), pp 150-158. Birkhäuser, Basel.

Yellen G (1982) Single $\mathrm{Ca}^{2+}$-activated non-selective cation channels in neuroblastoma. Nature 296:357-359. 